\title{
SERIES
}

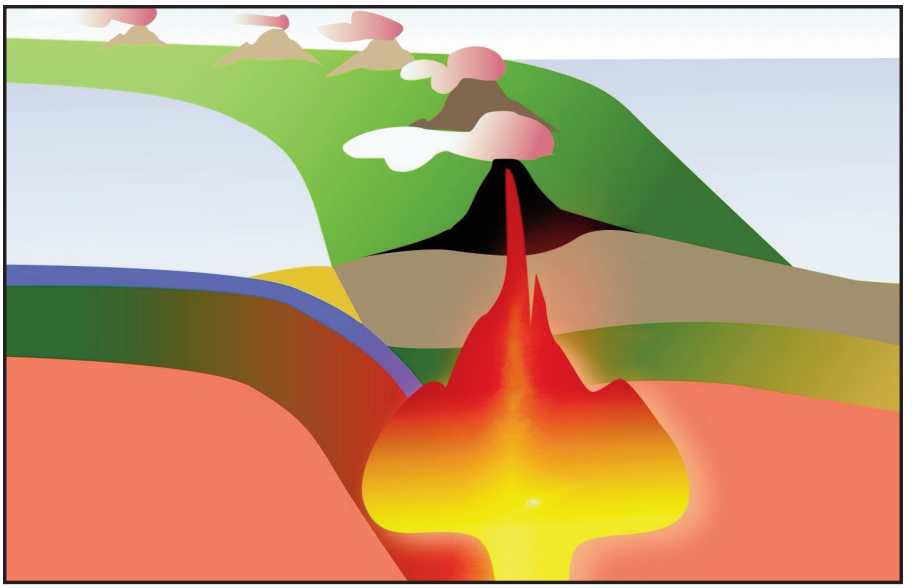

Igneous Rock Associations 18.

\section{Transition Metals in Oceanic Island Basalt: Relationships with the Mantle Components}

\author{
John D. Greenough and Kevin MacKenzie \\ Department of Earth and Environmental Sciences \\ SCI 216, University of British Columbia, Okanagan \\ 3333 University Way, \\ Kelowna, British Columbia, V1V 1V7, Canada \\ Email:john.greenough@ubc.ca
}

\section{SUMMARY}

Incompatible elements and isotopic ratios identify three endmember mantle components in oceanic island basalt (OIB); EM1, EM2, and HIMU. We estimate compatible to mildly incompatible transition metal abundance trends $(\mathrm{Ni}, \mathrm{Co}, \mathrm{Fe}$, $\mathrm{Cu}, \mathrm{Cr}, \mathrm{V}, \mathrm{Mn}, \mathrm{Sc}$, and $\mathrm{Zn})$ in 'primitive' basalt suites $(\mathrm{Mg} \#=$ $\mathrm{Mg} /(\mathrm{Mg}+0.9 * \mathrm{Fe})$ atomic $=0.72)$ from 12 end-member oceanic islands by regressing metals against $\mathrm{Fe} / \mathrm{Mg}$ ratios in sample suites, and solving for concentrations at $\mathrm{Mg} / \mathrm{Fe}=1$ $(\mathrm{Mg} \#=0.72)$. Using the transition metal estimates, exploratory statistics reveal that islands 'group' based on mantle component type even when $\mathrm{La} / \mathrm{Yb}$ ratios are used to compensate metal concentrations for percentage melting. Higher chalcophile $\mathrm{Zn}$ (and $\mathrm{Pb}$, earlier work) in EM1 and EM2 compared to HIMU, and higher $\mathrm{Cr}(3+)$ and $\mathrm{Sc}$ in HIMU relative to EM1, support views that HIMU represents subductionprocessed ocean floor basalt. Incompatible elements, ratios and isotopes indicate that EM1 is Archean, EM2 is Protero- zoic or younger, and both are related to sediment subduction. As found with incompatible elements, EM1 and EM2 show similar 'compatible' element concentrations, but lower (multivalence) $\mathrm{Cr}, \mathrm{Fe}$ and $\mathrm{Mn}$ in EM1 could indirectly reflect increasing oxidation of subducted sediment between the Archean and Proterozoic. Alternatively, changes in subduction processes that yielded peak continental formation in the Neoarchean, and craton-suturing in the Paleoproterozoic may account for EM1-EM2 differences. EM1 shows similar or lower Cr, Ni and Co compared to HIMU and EM2 suggesting that economic viability of layered intrusions, which have extreme EM1-like signatures, is unrelated to high metals in EM1 mantle sources, but that high $\%$ melting appears important. Because core-concentrated transition metals correlate with mantle component type, lithospheric recycling apparently controls their concentrations in OIB and core-mantle interaction may be unimportant.

\section{RÉSUMÉ}

Les éléments incompatibles et les rapports isotopiques permettent de délimiter trois termes extrêmes de composants mantéliques dans des basaltes insulaires océaniques (OIB), soit EM1, EM2, et HIMU. Nous estimons les tendances d'abondance de métaux de transition (Ni, Co, Fe, Cu, Cr, V, Mn, Sc, and $\mathrm{Zn}$ ) compatibles à modérément incompatibles dans des suites de basaltes " primitifs » $(\mathrm{Mg} \#=\mathrm{Mg} /(\mathrm{Mg}+0,9 * \mathrm{Fe})$ rayon atomique $=0,72$ ) sur 12 termes extrêmes de matériaux insulaires océaniques, par régression des concentrations des métaux sur les rapports $\mathrm{Fe} / \mathrm{Mg}$ dans des échantillons des suites, la détermination étant définie au rapport $\mathrm{Mg} / \mathrm{Fe}=1$ $(\mathrm{Mg} \#=0,72)$. L'utilisation d'une approche statistique exploratoire sur les estimations de métaux de transition montre que la composition des îles se « regroupent» en fonction du type de composition du manteau, cela même lorsque les ratios $\mathrm{La} / \mathrm{Yb}$ sont utilisés pour compenser les concentrations de métaux pour déterminer le pourcentuel de fusion. Le caractère plus chalcophile du $\mathrm{Zn}$ (et $\mathrm{Pb}$, travail antérieur) dans EM1 et EM2 comparé à HIMU, et la plus grande teneur en $\mathrm{Cr}(3+)$ et Sc dans HIMU par rapport à EM1, accréditent l'idée que HIMU représente le basalte de subduction des fonds océaniques. Les éléments incompatibles, les ratios et les isotopes montrent que EM1 est archéen, que EM2 est protérozoïque ou plus jeune, et que les deux sont liés à la subduction sédimentaire. Comme constaté pour les éléments incompatibles, EMI et EM2 affichent une compatibilité similaire des concentrations en éléments " compatibles", toutefois une concentration inférieure en $\mathrm{Cr}$ (multivalent), Fe et Mn dans EM1 pourrait refléter indirectement une oxydation croissante des sédiments subduits entre l'Archéen et le Protérozoïque. Par 
ailleurs, les changements dans les mécanismes de subduction qui ont mené à un maximum de formation continentale au Néoarchéen et à des épisodes de sutures cratoniques au Paléoprotérozoïque, peuvent expliquer les différences entre EM1 et EM2. La teneur similaire ou inférieure en $\mathrm{Cr}$, Ni et Co de EM1 par rapport à HIMU et EM2 permet de croire que la viabilité économique des intrusions stratifiées - lesquelles montrent des signatures extrêmes EM1 - est sans rapport avec les sources mantéliques à fortes teneurs en métaux, mais que le fort pourcentuel de fusion qui importerait. Parce que la concentration du noyau en métaux de transition correspond avec le type de composant du manteau, c'est le recyclage lithosphérique qui contrôle apparemment leurs concentrations dans l'OIB, et l'interaction noyau-manteau pourrait être sans importance.

Traduit par le Traducteur

\section{INTRODUCTION}

Incompatible elements and the small number of their radiogenic isotopic ratios have been paramount to providing a picture for evolution of the Earth's mantle. The prevailing view is that melt extraction of incompatible elements from the mantle has led to formation of incompatible-element depleted mid-ocean-ridge basalt (MORB) mantle (DMM), continental crust enriched in these elements, and 3+ oceanic island basalt (OIB) end-member mantle components bearing subductionrecycled materials including: enriched mantle 1 (EM1; sediment), enriched mantle 2 (EM2; sediment), and high $\mathrm{Mu}$ (high $\mu=$ high $\mathrm{U} / \mathrm{Pb}=\mathrm{HIMU}$; subduction-processed MORB) (Zindler and Hart 1986; Sun and McDonough 1989; Hofmann 1997; Bennett 2003; Hofmann 2003; Greenough et al. 2007). The oceanic islands with the most extreme isotopic and trace element concentrations, representing each of the mantle components, are well established (e.g. Zindler and Hart 1986; Hofmann 2003; Greenough et al. 2005b, 2007; see METHODS for caveats about individual samples, and chemical variation at individual islands). However, most incompatible element ratios and radiogenic isotopic ratios are unlikely to be sensitive to processes that would impact transition metals $(\mathrm{Fe}, \mathrm{Cu}, \mathrm{V}$, etc.) in basalt including source region mineralogy (e.g. Sobolev et al. 2005; Gurenko et al. 2009; Le Roux et al. 2011), subductionrecycled $\mathrm{Fe} / \mathrm{Mn}$-rich pelagic sediment in mantle sources (e.g. Scherstén et al. 2004), core-formation, or core-interaction processes involving deep mantle plumes (e.g. Humayun et al. 2004; Brandon and Walker 2005; Qin and Humayun 2008). Theoretically, siderophile (Goldschmidt classification) and ferrophile elements (elements important in mantle and crustal $\mathrm{Fe}-\mathrm{Mg}$-bearing phases) can help distinguish between hypotheses.

Studies of incompatible elements (e.g. $\mathrm{Ba}, \mathrm{Rb}, \mathrm{Nb}, \mathrm{La}$ ) in OIB source regions use ratios of similarly incompatible elements to minimize the impact of differentiation and the percentage of melting, and these ratios have been used for chemical characterization of the end-member mantle components (Allègre et al. 1995; Greenough et al. 2005b, 2007). Far fewer studies have used compatible elements to describe mantle heterogeneity because it has been challenging to deal with the effects of differentiation, the percentage of melting, and oxygen fugacity, but this is changing (e.g. Lee et al. 2005, 2010, 2012; Le Roux et al. 2010, 2011).
Our objective is to evaluate the hypothesis that the firstrow transition elements $\mathrm{Ni}, \mathrm{Co}, \mathrm{Fe}, \mathrm{Cu}, \mathrm{Cr}, \mathrm{V}, \mathrm{Mn}, \mathrm{Sc}$, and $\mathrm{Zn}$, which are variably 'compatible' to somewhat incompatible, have concentrations in OIB magmas and source regions that are correlated with mantle component type. We regressed each element against $\mathrm{Mg} / \mathrm{Fe}$ ratios in basaltic suites from twelve oceanic islands representing the most extreme examples of each of the end-member mantle components. The regressions compensate for differentiation and yield estimates of average element concentrations in 'primary' magmas. Incorporating proxies for the percentage of melting (e.g. La/Yb ratios) allows us to appraise the effect of melting on element concentrations. As many of these elements are siderophile or chalcophile, they were likely concentrated in the core during differentiation. Therefore, we also use our regressions to test the hypothesis that compatible element concentrations in OIB reflect core-mantle interaction. However, in contrast with the well-established, geochemistry-based data that characterize basalts from each of the mantle components, available seismic tomography information, for the depth of origin of OIBforming 'plumes,' has comparatively low 'resolution' making it challenging to conclusively test the core-mantle interaction hypothesis.

\section{METHODS \\ Data Selection and Preparation}

All raw data used in the paper were downloaded from the GEOROC web site (Sarbas and Nohl 2008) and are given in an Electronic Supplementary Materials file*, ESM Table-1. To estimate transition metal abundances in primary (undifferentiated) basaltic magmas, we regressed metal data for oceanic island basalts against $\mathrm{Mg} / \mathrm{Fe}$ (wt. \%) ratios (MacKenzie 2008). Twelve islands were used in this experiment, all identified as representatives of the end-member mantle components based on $\mathrm{Sr}, \mathrm{Nd}$, and $\mathrm{Pb}$ isotopic data (e.g. Zindler and Hart 1986; Hofmann 2003) and average trace element ratio data (e.g. Allègre et al. 1995; Greenough et al. 2005b, 2007). Islands used include EM1: Aitutaki, Gough, Heard, Kerguelen, and Pitcairn, EM2: São Miguel, Tahiti, Tutuila, and Upolu, and HIMU: Mangaia, St. Helena, and Tubuai. We recognize that the average isotopic and trace element ratio signature is not as strong for some islands as others within one component group. For example, average Pitcairn (an EM1 island) ${ }^{143} \mathrm{Nd} /{ }^{144} \mathrm{Nd}$ and ${ }^{87} \mathrm{Sr} /{ }^{86} \mathrm{Sr}$ ratios are higher and lower (respectively) than all other EM1 islands used in the study (i.e. least EM1-like; Greenough et al. 2005b) but they are distinct from all non-EM1 oceanic islands. Another issue is that there is chemical variability in basalt from any one island, but based on averaged isotopic and trace element data, each island listed above shows characteristics representative of the associated component source type. This is important because there are far more samples with transition metal data than with isotopic data, and those with isotopic data do not necessarily have complementary trace element or transition metal data. We use incompatible element data (incompatible element ratios) to confirm that the average composition of samples used to represent each island classifies it according to component type, and then test the hypothesis that transition metal concentrations in primary basalt occurrences also correlate with component type. Thus, we suggest that the regression analysis 
approach used here (see details below) will yield useful 'average' approximations of transition metal concentrations in primary magmas for each island and test the hypothesis that concentrations are related to component type. We acknowledge that this approach, which necessarily uses multiple samples, may not yield the most extreme source composition at one island, but should provide useful average transition metal data for each end-member island.

Many compatible to mildly incompatible, siderophile, chalcophile, and/or ferromagnesian mineral-associated elements were considered for analysis but elements such as $\mathrm{Au}$ and the platinum group elements (PGE) were eliminated because there were no data for $\geq 25 \%$ of the islands. Our study focuses on elements that are likely to have high concentrations in the core, such that core-mantle interaction should result in these elements being unrelated to the patterns seen in incompatible trace element ratios and lithophile element isotopic ratios that have been ascribed to lithosphere recycling. McDonough (2003) estimated that the core contains $93 \%$ of the planet's inventory of $\mathrm{Ni}$ and $\mathrm{Co}, 87 \%$ of the $\mathrm{Fe}, 60-65 \%$ of the $\mathrm{Cu}$ and $\mathrm{Cr}, 50 \%$ of $\mathrm{V}$ and $\sim 10 \%$ of the Mn. Ferrophile Sc and chalcophile $\mathrm{Zn}$ were included in the study because they are controlled by Fe-bearing minerals (Sc) and possibly sulphides $(\mathrm{Zn})$ in the mantle and crust, and although they are not considered significantly enriched in the core (McDonough 2003), they provide context for interpreting information from the other elements. Although some of these elements are rarely considered in studies on mantle chemical heterogeneity, all may be useful in evaluating relationships with mantle component type and unlike the PGE, they are commonly reported in geochemical studies of basaltic rocks.

After downloading the major element and trace element whole-rock data from the GEOROC website, several filters were used to screen the island data sets prior to statistical analysis. All rocks (analyses) had associated major element data determined by X-ray fluorescence (XRF) on glass discs, atomic absorption spectroscopy (AA) or emission spectroscopy. Most trace elements were determined by ICP-MS (inductively coupled plasma-mass spectrometry) or INA (instrumental neutron activation), with XRF on pressed powder pellets commonly used to determine $\mathrm{Ni}, \mathrm{Cr}$ and chalcophile elements such as $\mathrm{Cu}$ and $\mathrm{Zn}$. A small percentage of trace element data come from emission spectroscopy. Trace element precision and accuracy are generally between 5 and $10 \%$. Over $95 \%$ of trace element data are post-1970 but a few samples with earlier major element analyses contribute to assessments of Mn concentrations; we note that those used survived the regression screening process described in the next paragraph. As a check on data quality the major elements were summed and samples with values outside of the $98-102 \%$ range were omitted; and analyses that were normalized to $100 \%$ in the literature were eliminated. Similarly, only samples with loss on ignition (or total $\mathrm{H}_{2} \mathrm{O}$ ) $<4$ wt. $\%$ were kept, to avoid issues related to alteration. Finally, when doing the regression analyses to estimate transition metal concentrations in primary magmas from each end-member island, outliers and high-leverage samples were eliminated (see section Statistical Methods). Despite the above quality-control procedures, not all data will have the same precision and accuracy, and there may be systematic biases. In the case of $\mathrm{Mn}$, analyses are not of as high quality as the data reported in Humayun et al. (2004) for a small number of samples mostly from Hawaii. However, the large size of the data sets available from repositories such as GEOROC helps counter some of these problems (e.g. precision and inter-lab bias) because data come from numerous labs; the study involves nearly 700 rocks, and over 5000 analyses of 9 elements. Secondly, exploratory statistics are used to uncover patterns in the chemical data and samples, using all data simultaneously. If patterns emerge that are clearly relatable to wellestablished geological factors (e.g. if islands have overall transition metal geochemistry that is tied to the type of mantle component) then these patterns are unlikely to be fortuitous. Thirdly, any patterns that do emerge from such large data sets are likely to be of planetary importance and it is difficult to use small data sets to uncover large-scale patterns. As suggested by Le Roux et al. (2010) who looked at Fe/Zn/Mn relationships in OIB, there is little alternative but to try using the available world-wide data set at this time.

Highly differentiated samples were not used. The degree of differentiation was estimated from $\mathrm{Mg} \#$ values $[\mathrm{Mg} \#=$ $\mathrm{Mg} /\left(\mathrm{Mg}+\left(0.9 * \mathrm{Fe}^{\mathrm{t}}\right)\right)$ atomic] which decrease with differentiation because $\mathrm{Mg}$ enters octahedral sites in $\mathrm{Fe}-\mathrm{Mg}$ silicates in preference to $\mathrm{Fe}$ (Basaltic Volcanism Study Project 1981). Samples with $\mathrm{Mg} \#<0.4$ were omitted. Iron is reported in the literature various ways. All iron was recalculated as $\mathrm{FeO}^{\mathrm{t}}$ (total $\mathrm{Fe}$ as wt. \% FeO). Although samples bearing accumulated ferromagnesian phases could have $\mathrm{Mg \#}$ values $\geq 0.4$ despite a magma $\mathrm{Mg} \#<0.4$, the regression procedure used to estimate transition element abundances in primary magmas eliminated outliers and high-leverage samples. Thus, if phenocryst accumulation had a significant impact on trace element composition, the sample was eliminated when the regression analyses were performed (see section Statistical Methods).

In preparation for statistical analysis, $\mathrm{Mg} / \mathrm{Fe}^{t}$ ratios (wt. \% of cations) were calculated and used as the independent variable in the regression analyses. Transition metal abundances were estimated from the regression analyses assuming primary magmas have a $\mathrm{Mg} / \mathrm{Fe}^{t}$ ratio of 1.0. This ratio translates into a $\mathrm{Mg} \#$ value of 0.72 , and primary magmas formed in equilibrium with $\sim \mathrm{FO}_{90}$ olivine should show $\mathrm{Mg} \#$ values between 0.70 to 0.72 with an exchange coefficient value $\left(\mathrm{K}_{\mathrm{D}}{ }^{\mathrm{Mg}-\mathrm{Fe}}{ }_{\mathrm{Ol-Liq}}=\right.$ $\left.\left(\mathrm{X}_{\mathrm{Liq}}^{\mathrm{Mg}} / \mathrm{X}_{\mathrm{Ol}}^{\mathrm{Mg}}\right) /\left(\mathrm{X}_{\mathrm{Liq}}^{\mathrm{Fe} 2+} / \mathrm{X}^{\mathrm{Fe} 2+}{ }_{\mathrm{O}}\right)\right)=0.3$ (Roeder and Emslie 1970). Olivine is by far the dominant mineral found in mantle xenoliths and it generally has a composition close to $\mathrm{Fo}_{90}$ (ibid). Recent experiments have shown that $\mathrm{K}_{\mathrm{D}}{ }^{\mathrm{Mg}-\mathrm{Fe}}{ }_{\mathrm{Ol-Liq}}$ is dependent on temperature, olivine composition and melt composition but the observation that it tends to be close to 0.3 in natural systems is because the effects of these parameters cancel out (Toplis 2005; Matzen et al. 2011). Thus, these authors noted that a $\mathrm{K}_{\mathrm{D}}{ }_{\mathrm{Mg}-\mathrm{Fe}}$ Ol-Liq value of $0.3\left(\mathrm{Mg} \#=0.72\right.$ atomic and $\mathrm{Mg} / \mathrm{Fe}^{t}$ $=1 \mathrm{wt} . \%)$ is a convenient reference point for general petrological studies. The debate about whether primary basaltic magmas can originate from non-olivine sources spans decades (Basaltic Volcanism Study Project 1981) and although a common view is that magmas form in the presence of olivine, there is no unanimous agreement (e.g. Kogiso et al. 2003; Keshav et al. 2004, 2006; Sobolev et al. 2005; Lustrino 2006). We note that there are a few, non-cumulus samples present in the majority of island suites ( 8 of 12 suites) that have $\mathrm{Mg} \#$ values between 0.69 and 0.71 (Table 1 ) suggesting that $\sim 0.70$ is a 
Table 1: Estimates of transition metal concentrations in primary magmas for 12 oceanic islands representing EM1, EM2, and HIMU mantle components.

\begin{tabular}{|c|c|c|c|c|c|c|c|c|c|c|c|c|}
\hline $\begin{array}{l}\text { Island } \\
\text { Type } \\
\text { Depth } \\
\text { Plot Abbrev. }\end{array}$ & $\begin{array}{r}\text { Aitutaki } \\
\text { EM1 } \\
\sim 2800 \\
\mathrm{Ai}\end{array}$ & $\begin{array}{r}\text { Gough } \\
\text { EM1 } \\
\text { Unseen } \\
\text { Go }\end{array}$ & $\begin{array}{r}\text { Heard } \\
\text { EM1 } \\
\sim 2800 \\
\text { He }\end{array}$ & $\begin{array}{r}\text { Kerguelen } \\
\text { EM1 } \\
\sim 2800 \\
\mathrm{Ke}\end{array}$ & $\begin{array}{r}\text { Pitcarin } \\
\text { EM1 } \\
\text { Unseen } \\
\text { Pi }\end{array}$ & $\begin{array}{r}\text { São Miguel } \\
\text { EM2 } \\
\sim 2800 \\
\mathrm{Sa}\end{array}$ & $\begin{array}{r}\text { Tahiti } \\
\text { EM2 } \\
\sim 2800 \\
\mathrm{Ta}\end{array}$ & $\begin{array}{r}\text { Tutuila } \\
\text { EM2 } \\
\sim 2800 \\
\mathrm{Tu}\end{array}$ & $\begin{array}{r}\text { Upolu } \\
\text { EM2 } \\
\sim 2800 \\
\text { Up }\end{array}$ & $\begin{array}{r}\text { Mangaia } \\
\text { HIMU } \\
\sim 2800 \\
\mathrm{Ma}\end{array}$ & $\begin{array}{r}\text { St Helena } \\
\text { HIMU } \\
\text { Unseen } \\
\text { St }\end{array}$ & $\begin{array}{r}\text { Tubuai } \\
\text { HIMU } \\
\sim 2800 \\
\mathrm{~Tb}\end{array}$ \\
\hline \multicolumn{13}{|c|}{ Transition metal estimates } \\
\hline $\mathrm{Cr}$ & 256 & 444 & 669 & 309 & 606 & 957 & 823 & 1041 & 754 & 1146 & 870 & 1099 \\
\hline $\mathrm{Ni}$ & 283 & 417 & 506 & 363 & 427 & 328 & 435 & 500 & 567 & 471 & 366 & 362 \\
\hline Co & 53 & 71 & 116 & 71 & 38 & 46 & 79 & 98 & 62 & 86 & 74 & 76 \\
\hline Sc & & 25 & 27 & 28 & & 29 & 74 & & 20 & 52 & 56 & 51 \\
\hline $\mathrm{V}$ & & 195 & 286 & 396 & 187 & 283 & 301 & 236 & 217 & 205 & 427 & 255 \\
\hline $\mathrm{Zn}$ & 95 & 100 & 106 & 147 & 90 & 86 & 124 & 93 & 115 & 79 & 84 & 88 \\
\hline $\mathrm{Cu}$ & 44 & 45 & 77 & 41 & 83 & 94 & 71 & 67 & 58 & 218 & 97 & 135 \\
\hline $\mathrm{Mn}$ & 1221 & 1117 & 1244 & 1265 & 739 & 1308 & 1363 & 1336 & 1213 & 1432 & 1016 & 1394 \\
\hline $\mathrm{Fe}$ & 76855 & 85325 & 91466 & 84593 & 47904 & 98612 & 96639 & 91292 & 103299 & 90441 & 93851 & 88753 \\
\hline $\mathrm{Fe} / \mathrm{Mn}$ & 63 & 76 & 74 & 67 & 65 & 75 & 71 & 68 & 85 & 63 & 92 & 64 \\
\hline $\mathrm{Zn} / \mathrm{Fe}(* 104)$ & 12.4 & 11.7 & 11.6 & 17.3 & 18.8 & 8.7 & 12.9 & 10.1 & 11.2 & 8.8 & 9.0 & 9.9 \\
\hline \multicolumn{13}{|c|}{ Percentage of melting proxies } \\
\hline $\mathrm{La} / \mathrm{Yb}$ & 38.8 & 23.8 & 27.1 & 27.7 & 22.1 & 21.1 & 22.0 & 11.7 & 23.4 & 18.6 & 22.0 & 29.9 \\
\hline $\mathrm{Nb} / \mathrm{Y}$ & 2.29 & 1.75 & 1.80 & 0.93 & 1.30 & 2.13 & 1.65 & 0.75 & 1.60 & 1.84 & 2.04 & 2.77 \\
\hline \multicolumn{13}{|c|}{ Maximum $\mathrm{Mg} / \mathrm{Fe}$ ratio and $\mathrm{Mg \#}$} \\
\hline $\mathrm{Mg} / \mathrm{Fe}$ & 0.94 & 0.87 & 0.97 & 0.92 & 0.48 & 0.96 & 0.97 & 0.93 & 0.76 & 0.81 & 0.81 & 0.91 \\
\hline $\mathrm{Mg \#}$ & 0.71 & 0.69 & 0.71 & 0.70 & 0.55 & 0.71 & 0.71 & 0.70 & 0.66 & 0.67 & 0.67 & 0.70 \\
\hline
\end{tabular}

Notes: All concentrations in ppm. Type $=$ Mantle component type. Plot Abbrev. $=$ Abbreviated island name on plots.

Transition metal estimates $=$ regression results at $\mathrm{Mg} / \mathrm{Fe}($ ratio in wt. $\%$ of cations with $\mathrm{Fe}=$ total $\mathrm{Fe})=1=\mathrm{Mg} \#(\mathrm{Mg} /(\mathrm{Mg}+0.9 * \mathrm{Fe}$ total $)$ atomic $)=0.72$. Percentage of melting proxies = element ratios that are dominantly controlled by the percentage of melting.

Maximum $\mathrm{Mg} / \mathrm{Fe}$ and $\mathrm{Mg} \#=$ maximum values of $\mathrm{Mg} / \mathrm{Fe}$ ratio and $\mathrm{Mg} \#$ (both defined above) in each island data set.

Depth $=$ imaged plume depth from Montelli et al. (2006). Unseen $=$ there is no evidence for a plume.

Note that for 'unseen' Gough there is no obvious low velocity zone in this area.

Both Pitcairn and St. Helena are somewhat isolated oceanic islands. Neither is associated with a 'plume' low velocity zone.

Tubuai is $650 \mathrm{~km} \mathrm{~S}$ of Tahiti but within the low velocity zone centred on Tahiti. Tubuai depth is for the Tahiti plume though on a different hot-spot trace.

common upper value for a primary magma regardless of the source mineralogy (see also Greenough et al. 2005b). A final point is that any study of transition metals in OIB has to make assumptions (usually using $\mathrm{Mg} / \mathrm{Fe}$ ratios or $\mathrm{Mg}$ concentrations) about what constitutes a primary or primitive magma and consider how element concentrations or ratios are impacted by melting and differentiation (e.g. Humayun et al. 2004; Le Roux et al. 2010). This paper assumes that primary magmas have $\mathrm{Mg} \#$ values between 0.69 and 0.72 .

Fifty incompatible element ratios were calculated from pairs of similarly incompatible elements (elements separated by $<10$ elements in the Sun and McDonough (1989) incompatibility list) following procedures outlined by Greenough et al. (2005b, 2007). These ratios are used to confirm the geochemical character or mantle component type of islands in the Transition Metals and Mantle Components section of the paper.

Ratios for $\mathrm{Nb} / \mathrm{Y}$ and $\mathrm{La} / \mathrm{Yb}$ (i.e. ratios from element pairs with very different incompatibility) act as proxies for the percentage of melting. Although theoretically impacted by source composition, they are overwhelmingly controlled by the percentage of melting as surmised by Kay and Gast (1973) and Pearce and Cann (1973), and Pearce (1996) used Nb/Y ratios to separate basalt occurrences into alkaline and tholeiitic clans. Both Allègre et al. (1995) and Greenough et al. (2007) used exploratory statistical methods and trace element ratios (12 and 135 , respectively) to show that ratios sort oceanic basalt into groupings that correspond with the isotope-defined mantle components. However, both studies found that ratios calculated from element pairs that have distinctly different incompatibility provide little or no information on source type. Further, Greenough et al. (2007) showed that all extremely dissimilarly incompatible element ratios (i.e. calculated from elements separated by $\geq 20$ elements in the Sun and McDonough (1989) list) are highly correlated with one another, which is what is predicted if the percentage of melting controls ratio values. $\mathrm{La}$ and $\mathrm{Yb}$ are separated by $\sim 25$ elements on the Sun and McDonough (1989) list and we conclude that ratio values dominantly reflect the percentage of melting and provide a useful proxy for the percentage of melting.

The final step in the preparation of the dataset was to average the major elements, trace elements and incompatible element ratios for each individual island though these data are not used to estimate transition metal concentrations in 'primary' magmas from each island.

\section{Statistical Methods}

Linear regression was used to estimate transition element concentrations in 'primitive' magmas $(\mathrm{Mg} \#=0.72=(\mathrm{Mg} /(\mathrm{Mg}+$ $\left.0.9 * \mathrm{Fe}^{\text {total }}\right)$ atomic $)=\mathrm{Mg} / \mathrm{Fe}^{\text {total }}$ wt. $\%$ of cations $\left.=1.00\right)$ in each 
end-member mantle component oceanic island. Default algorithms in SYSTAT v. 13 software identified outliers and highleverage samples and in an iterative procedure, up to $20 \%$ of the data, for any one transition metal from one island, was eliminated to minimize the impact of outliers and high-leverage samples on the regression analyses. Anomalous data can come from human mistakes (sample mix-ups in the field, analytical errors, typographical errors, etc.) or natural processes (phenocryst accumulation, sample alteration, etc.) all of which can escape the major element total and LOI screens. The outlier and high-leverage sample screening eliminated those samples, but in general over $90 \%$ of the samples were retained in making primary-magma element concentration estimates from the regression analysis.

Next, we employed a powerful 'exploratory' statistical method, multidimensional scaling (MDS), and SYSTAT v. 13 software, to find the 'big picture' relationships between the islands using all the regression-derived transition metal data simultaneously. Exploratory data analysis techniques such as MDS and principal component analysis (PCA) cannot use information about possible sample relationships/groupings to influence results; sample relationships on plots simply reflect the geochemical data describing individual samples. MDS resembles PCA but is known for its ability to summarize variance in a small number of dimensions (Wilkinson et al. 1992; Borg and Groenen 1997, p. 1-14). Other advantages over PCA are that sample groups with small differences are not amalgamated, and the algorithms do not attempt to 'statistically' define sample groups. Thus the geochemist can look for groupings that reflect processes (e.g. \% melting) or resemble groupings known about from other geochemical data (e.g. mantle components based on isotopes). However, MDS does not preserve the absolute distance between samples and without statistical grouping, output does not identify and weight geochemical parameters (i.e. individual transition metals and their concentrations) that create groups in PCA.

MDS produces 'maps' of island relationships with relative positioning given by Dimension 1 and Dimension 2 coordinates. Similar objects (islands) plot close together on a MDS diagram ('map') and dissimilar objects plot far apart. Matrices of island-versus-island Pearson correlation coefficients were used as distance measures that act as input for the MDS calculations. If the elements (transition metals from regression analysis) in each island were plotted against analogous concentrations in all other islands, two islands with identical transition metal abundances would produce a perfectly straight correlation line and yield a correlation coefficient of 1. These two islands would tend to plot atop one another on a MDS diagram but the correlation coefficients are only approximations of how similar two islands are. As an analogy, given a geographic map, accurate distance measurements from three points to a fourth determine the position of the fourth point. In the case of the OIB, the position of each island on the MDS 'map,' which is based on island-versus-island Pearson correlation coefficients calculated from the regression-determined transition metal concentrations, is over-determined because with 12 islands, there are 11 distances from one island to the other 11 . The position of the $12^{\text {th }}$ island is over-determined and the job of the MDS algorithms (the loss function) is to optimally place each island on the 'map,' relative to all other islands, given that the Pearson correlation coefficients, measuring geochemical 'distances' between islands, are only 'estimates.' Calculations proceeded as follows: 1) All elements were $\mathrm{z}$-scored (standardized) to put them on the same scale so that each contributed equally to assessments of similarity; 2) a matrix of island-versus-island correlation coefficients was calculated from the z-scored data; and 3) this matrix was used along with linear MDS and a Kruskal loss function (SYSTAT default) to create the diagrams. MDS can also be used to compare the behaviour of chemical data; for example, when $\mathrm{Ni}$ is high are there other elements that tend to be high, or elements that behave the opposite of Ni? To compare chemical data, a matrix of element-versus-element correlation coefficients was calculated from z-scored data (step 2 above).

\section{RESULTS/DATA}

The linear regressions gave equations for lines through the transition metal-versus- $\mathrm{Mg} / \mathrm{Fe}$ data for each island, and solving the equations for a $\mathrm{Mg} / \mathrm{Fe}$ ratio of 1 (i.e. $\mathrm{Mg} \#=0.70$ ) yielded the concentrations of nine transition metals in hypothetical primitive basalt from 12 oceanic islands (Table 1). Raw data for these regressions appears in Electronic Supplementary Materials ${ }^{1}$ ESM Table-1, and plots of all regressions are given in ESM Table-2, with information on the regression lines (slope, intercept, probabilities = p-values) in ESM Table-3.

The results involved $\sim 100$ regressions that utilized over 600 rock samples. Every regression was plotted, visually inspected, and linearity confirmed (see caveats below) though some elements at some islands did not change in concentration with changing $\mathrm{Mg} / \mathrm{Fe}$. This confirmation of linearity is important because one could argue that changes in the phases or proportions of phases precipitating during differentiation could produce curved or kinked $\mathrm{Mg} / \mathrm{Fe}$-versus-element plots resulting in inaccurate estimates of element concentrations at $\mathrm{Mg} / \mathrm{Fe}=1$. Complicated scenarios where a phase was precipitated/removed from a magma, and then added back in (e.g. xenolith addition), resulting in a magma $\mathrm{Mg} / \mathrm{Fe}$ ratio resembling that from before the phase was removed, are possible. However, if the process resulted in the sample plotting significantly off the $\mathrm{Mg} / \mathrm{Fe}$-versus-transition metal regression line, our screening procedure that eliminated outliers ensured that the sample was removed. We conclude that, regardless of what minerals, mineral compositions or proportions of minerals are responsible for the linear relationships, they provide useful approximations of element concentrations in a 'primary' magma.

Figure 1 shows a few typical regressions (see ESM Table-2 for all plots). Averages (there are 12 islands) of the percentage errors on regression estimates for elements range from $6.3(\mathrm{Fe})$ to 23 (Cu; see ESM Table-3) and average p-values (probabilities) on the correlation coefficients are between 0.004 and 0.027 (see ESM Table-3) indicating that the correlations tend 

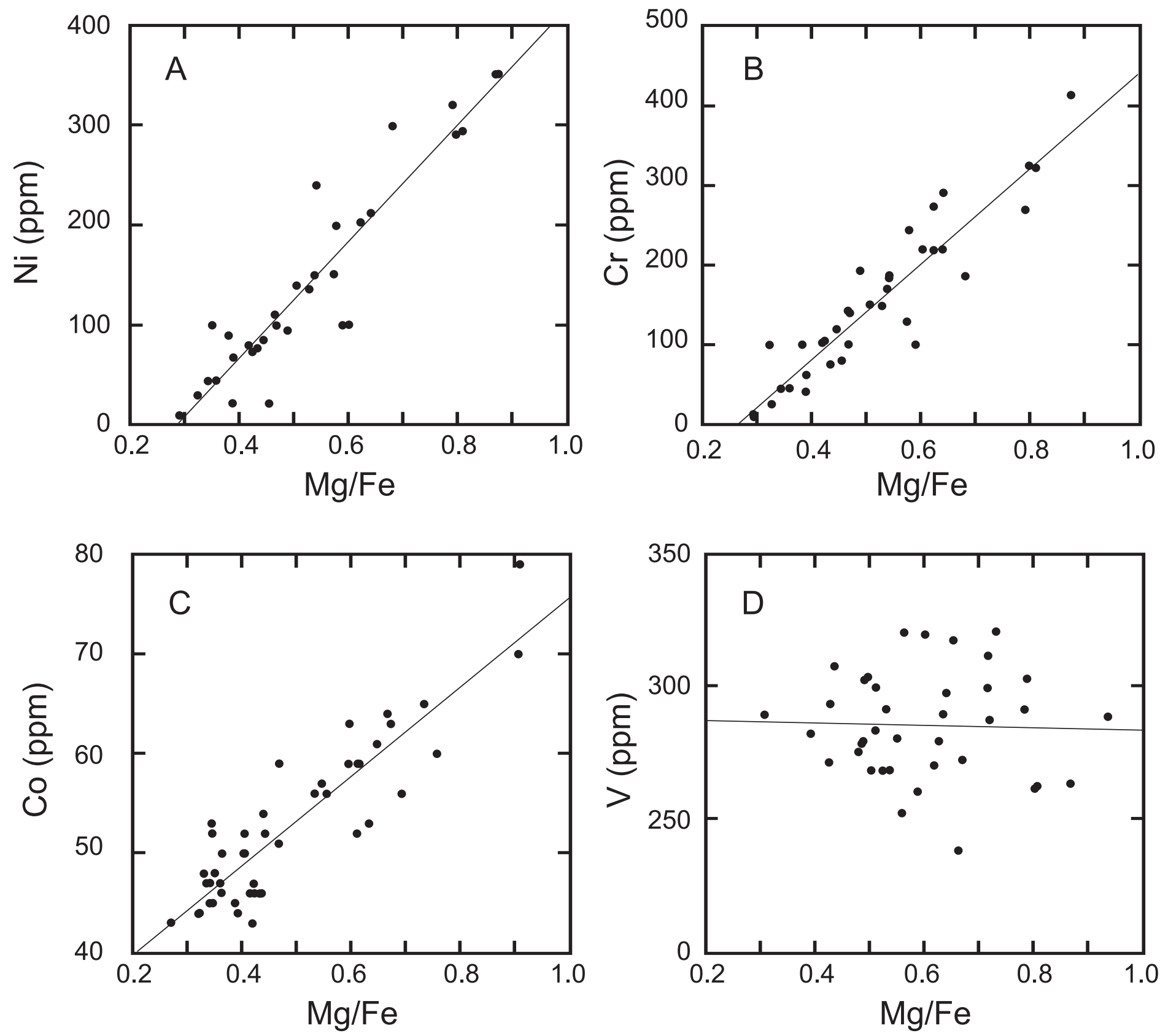

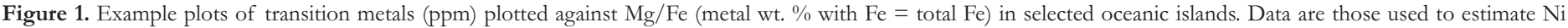

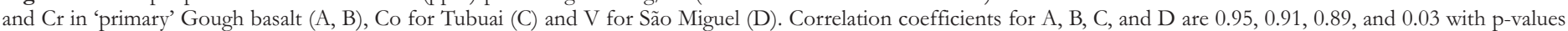

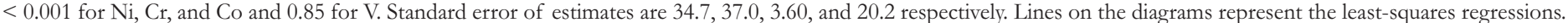
All of the $\sim 100 \mathrm{Mg} / \mathrm{Fe}$ regressions are shown in Electronic Supplementary Materials ESM Table-2. See text for discussion.

to be strong and estimates of element concentrations should yield useful approximations of transition metal abundances in primary magmas. Some elements show little change in concentration with changing $\mathrm{Mg} / \mathrm{Fe}$ and so slopes on the regressions approach zero. An example is $\mathrm{V}$ in São Miguel basalt (Fig.1D; correlation coefficient, $\mathrm{r}=0.03$ ) and others can be identified with the \% slope values in ESM Table-3. A low (absolute value) \% slope indicates that the element is at the boundary between being compatible (decreases with diminishing $\mathrm{Mg} / \mathrm{Fe}$ ) and incompatible during differentiation. The data set for Kerguelen shows weaknesses with a few elements (Co, $\mathrm{V}, \mathrm{Cu}$ ) represented by only three samples in the regressions (ESM Table -3). Similarly, Co, V, Zn and $\mathrm{Cu}$ are only repre- sented by three samples in the Tutuila data set. Most islands have a few samples with $\mathrm{Mg} / \mathrm{Fe}$ values greater than $0.80(\mathrm{Mg \#}$ $>0.67$ ) (Table 1 and ESM Table-3) which provide assurance that the regression results can be extrapolated to a $\mathrm{Mg} / \mathrm{Fe}$ ratio of 1.0. Eight of the twelve islands have samples within the range for a primary magma $(\mathrm{Mg} / \mathrm{Fe} \geq 0.87$ or $\mathrm{Mg} \#$ between 0.69 and 0.72 ). Just as importantly, these data show that primitive magmas with geochemistry consistent with pre-differentiation formation from $\mathrm{Fo}_{90}$ olivine-bearing peridotite exist on most islands. Upolu and Pitcairn have the lowest maximum $\mathrm{Mg} / \mathrm{Fe}$ ratios of 0.76 and 0.48 (respectively; $\mathrm{Mg} \#=0.66,0.55$ ) and thus required the most extrapolation to estimate primary magma compositions. Irrespective of what the statistical data 
suggest (e.g. high r, low p, small estimated percentage error; see ESM Table-3) the results for these islands need to be treated with more caution.

Le Roux et al. (2011) gave average Ni, Co, Zn, Mn, and Fe in EM1 (Pitcairn), and EM2 (Samoan Islands) and HIMU (Austral-Cook Islands) apparently derived from information in Jackson and Dasgupta (2008). Most values are within 10\% of average EM1, EM2 and HIMU using data in Table 1, with two $\sim 15 \%$ different, and three $20-25 \%$ different. Thus our results are quite similar, but more detailed comparisons are difficult because the results here are more comprehensive.

$\mathrm{The} \mathrm{Mg} / \mathrm{Fe}$ regression results (e.g. Fig. 1) compensate for differentiation in estimating transition metal abundances in primary magmas, but differences in element concentrations between islands and/or the mantle component types EM1, EM2, HIMU may be impacted by the percentage of melting. Figure 2 shows four example elements (Ni, $\mathrm{Cr}, \mathrm{Zn}$ and $\mathrm{Cu}$ ) plotted against average $\mathrm{La} / \mathrm{Yb}$ (a proxy for the percentage of melting) for each island, confirming that concentrations can be affected by the percentage of melting. Results for all nine elements are summarized as follows. Ni, Cr (Fig. 2) and Mn show moderately strong to weak negative correlations with $\mathrm{La} / \mathrm{Yb}(\mathrm{r}$ $=-0.60,-0.61$ and -0.29 with $\mathrm{p}=0.029,0.026$, and 0.34; respectively). Zinc provides an example of a modestly positive correlation, and $\mathrm{Cu}$ shows no significant correlation with $\mathrm{La} / \mathrm{Yb}$ (Fig. 2). Correlation coefficients for V, Fe, Zn, Co, Sc, and $\mathrm{Cu}$ are $0.550 .45,0.41,0.340 .09$ and 0.03 with $\mathrm{p}=0.07$, $0.13,0.16,0.26,0.81$ and 0.92 (respectively).

\section{DISCUSSION \\ Element Relationships and Percentage Melting}

Element behaviour during melting was qualitatively assessed using MDS. Each element in Table 1 was z-scored to put it on the same scale, a matrix of element-versus-element Pearson correlation coefficients was prepared, and this matrix used to create a multidimensional scaling (MDS) 'map' (Fig. 3). Proxies for the percentage of melting $(\mathrm{La} / \mathrm{Yb}, \mathrm{Nb} / \mathrm{Y}$ and their inverse ratios; e.g. Kay and Gast 1973; Pearce and Cann 1973) were included in all steps of the MDS calculations. Objects (elements or element ratios) showing the strongest antithetic behaviour tend to plot across the $\mathrm{X}$-axis (Dimension 1) of MDS diagrams. Objects showing weaker antithetic behaviour and generally reflecting a subsidiary process, plot along the Yaxis (Dimension 2). Simple X-Y plots of $\mathrm{La} / \mathrm{Yb}$ versus $\mathrm{Yb} / \mathrm{La}$ or $\mathrm{Nb} / \mathrm{Y}$ versus $\mathrm{Y} / \mathrm{Nb}$ will yield perfect negative correlations $(\mathrm{r}=-1)$. Thus, $\mathrm{La} / \mathrm{Yb}$ and $\mathrm{Yb} / \mathrm{La}$ should occur on opposite sides of a MDS diagram along Dimension 1 , and $\mathrm{La} / \mathrm{Yb}$ and $\mathrm{Nb} / \mathrm{Y}$ (as well as $\mathrm{Yb} / \mathrm{La}$ and $\mathrm{Y} / \mathrm{Nb}$ ) should plot close together if controlled by the percentage of melting. Figure 3 shows this is the case. Slight separation of $\mathrm{La} / \mathrm{Yb}$ and $\mathrm{Nb} / \mathrm{Y}$ (they do not plot exactly atop one another) is consistent with source composition having some effect on the plotting position of the two ratios. Significantly, Ni occurs close to and between $\mathrm{Y} / \mathrm{Nb}$ and $\mathrm{Yb} / \mathrm{La}$ on the opposite side of the diagram from $\mathrm{La} / \mathrm{Yb}$ and $\mathrm{Nb} / \mathrm{Y}$. We conclude that $\mathrm{Ni}$ is strongly compatible and as the percentage of melting goes up, $\mathrm{Ni}$ concentrations increase, and $\mathrm{La} / \mathrm{Yb}$ and $\mathrm{Nb} / \mathrm{Y}$ ratios go down. Other apparently compatible elements on the left-side of Figure 3 include $\mathrm{Co}$ and Cr. Most other transition metals plot between values of 0 and 1 along Dimension 1 suggesting they are slightly incom- patible, but they are also affected by a secondary process, such as source region composition, that causes them to plot along Dimension 2 with $\mathrm{Zn}$ behaving antithetically to $\mathrm{Cu}$ and Sc (Fig. 3). Possible causes for these $\mathrm{Zn}-\mathrm{Cu}-\mathrm{Sc}$ relationships are examined below, where origins of the mantle components are discussed.

Transition metal concentrations in Table 1 were regressed against average $\mathrm{La} / \mathrm{Yb}$ ratios using all islands regardless of whether they were EM1, EM2 or HIMU islands. The data produce clear, highly significant $(\mathrm{p}<0.06)$ trends for $\mathrm{Ni}$ and $\mathrm{Cr}$ (Fig. 2); separate regressions by individual mantle type do not appear to be justified. Table 2 gives all regression results (slope, intercept, correlation coefficient, probability) and shows that apart from $\mathrm{Ni}$ and $\mathrm{Cr}$, most elements are moderately to poorly correlated with $\mathrm{La} / \mathrm{Yb}$. Negative slopes indicate compatible behaviour and positive slopes modest incompatibility, though an alternative interpretation is that temperature affects bulk partitioning coefficients. Bulk partitioning coefficients cannot be determined without many assumptions but, taking the regression results at face value, relative compatibility or incompatibility of elements during melting can be estimated by using the regression equations to calculate an enrichment or depletion factor. The column labelled 'Factor' in Table 2 gives the ratio of the concentration of an element at $\mathrm{La} / \mathrm{Yb}=10$ divided by the concentration of the element at $\mathrm{La} / \mathrm{Yb}=40$, for compatible elements, with the concentrations determined from the overall regression equations. Similarly, for somewhat incompatible elements Factor was calculated from the concentration at $\mathrm{La} / \mathrm{Yb}=40$ divided by that at $\mathrm{La} / \mathrm{Yb}=10$. The Factor values were assigned + and - signs depending on whether the element was incompatible or compatible. These Factor values suggest that $\mathrm{Cr}, \mathrm{Sc}, \mathrm{Cu}, \mathrm{Ni}, \mathrm{Co}, \mathrm{Fe}$, and $\mathrm{Mn}$ are compatible (decreasing compatibility in that order), and $\mathrm{Zn}$ and $\mathrm{V}$ may show modest incompatibility. Lee et al. (2005) indicated that $\mathrm{V}$ and Sc should show somewhat similar compatibility during melting of spinel lherzolite but in the presence of garnet, the case for OIB, they note that Sc will become more compatible.

We caution that the low correlation coefficients with high $p$-values $(\geq 0.5)$ for many of these regressions suggest the estimates of relative compatibility or incompatibility are crude. However, a similar analysis of relative compatibility performed on the $\mathrm{Mg} / \mathrm{Fe}$ regressions indicates decreasing compatibility during differentiation in the order $\mathrm{Cr}, \mathrm{Ni}, \mathrm{Sc}, \mathrm{Cu}, \mathrm{Co} \mathrm{Fe}, \mathrm{V}, \mathrm{Mn}$, $\mathrm{Zn}$ with a change from compatible to incompatible around $\mathrm{Fe}$ and $\mathrm{V}$. Thus, to a first approximation, the inferred order of compatibility is very similar during melting and differentiation.

Lee et al. (2012) reviewed $\mathrm{Cu}$ concentrations in arc magmas and MORB and modelled the effect of source $\mathrm{Cu}$ and $\mathrm{S}$ concentration, mineral modes and oxygen fugacity $\left(f\left(\mathrm{O}_{2}\right)\right)$ on magma $\mathrm{Cu}$ concentrations. Their results suggest that the oxygen fugacity in MORB and arc sources must be low enough to keep $S$ in the $S^{2-}$ state, which stabilizes sulphide phases and makes $\mathrm{Cu}$ compatible, because both have low, nearly identical primary magma $\mathrm{Cu}$ concentrations $(60-70$ and $50-90 \mathrm{ppm}$, respectively). As noted above, taken at face value, the $\mathrm{La} / \mathrm{Yb}$ regression suggests that $\mathrm{Cu}$ is overall compatible (Fig. 2; Table $2)$, indicating that, like MORB and arc sources, $f\left(\mathrm{O}_{2}\right)$ is low enough to stabilize sulphide phases. Further, our mean concentrations for $\mathrm{Cu}$ in EM1 and EM2 magmas (58 and 73 ppm, respectively) are essentially identical to those for MORB and 

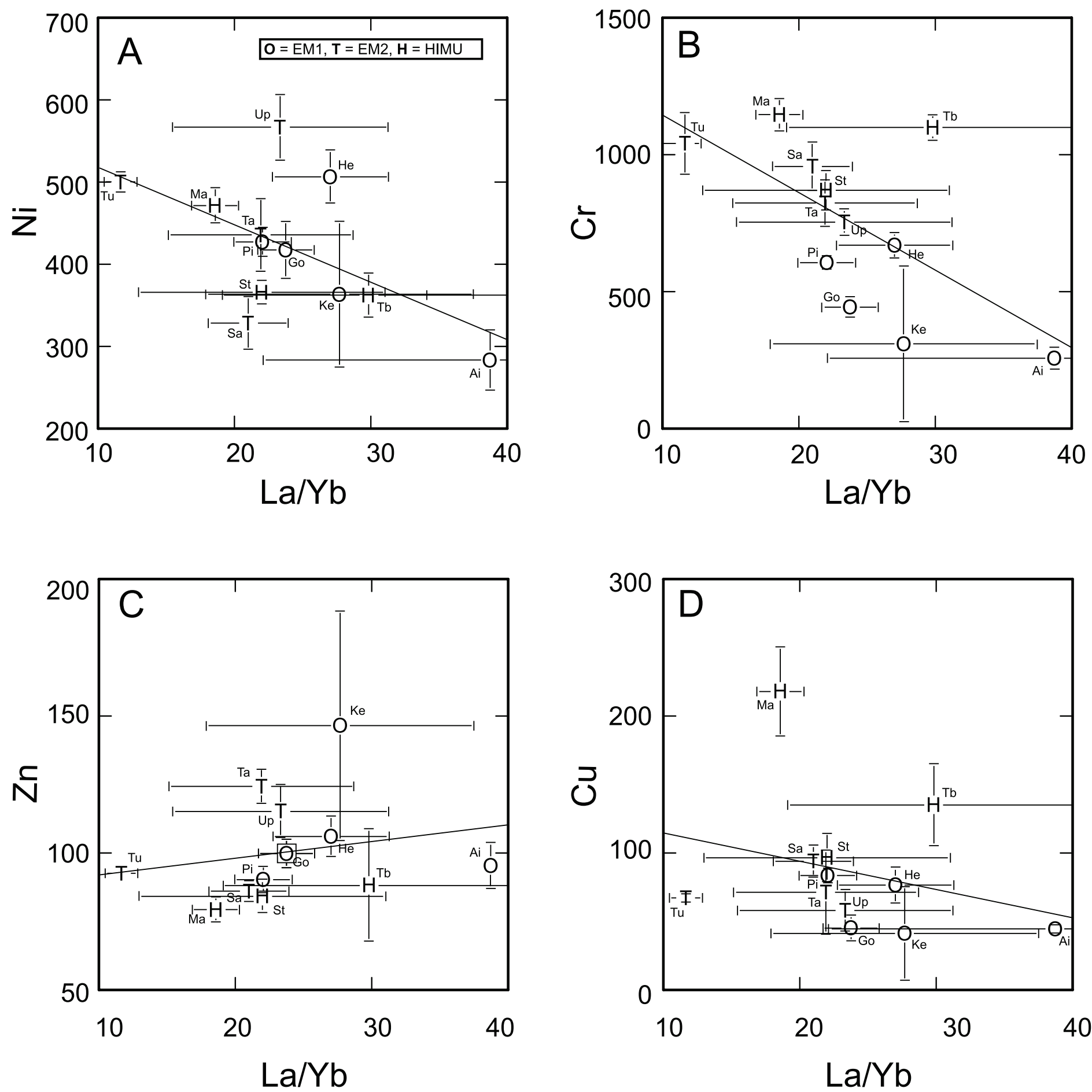

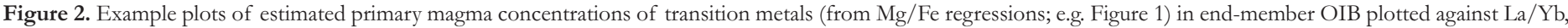

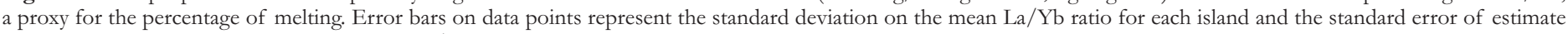

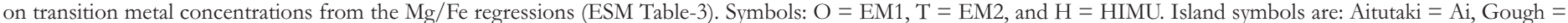

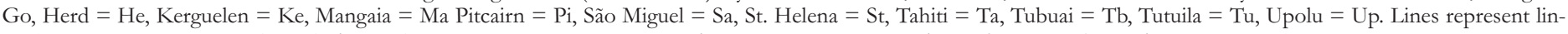
ear least squares regression through data with $\mathrm{r}=-0.56,-0.62,0.21,-0.28$ and $\mathrm{p}=0.06,0.03,0.52$, and $0.39 \mathrm{for} \mathrm{Ni}$, $\mathrm{Cr}$, $\mathrm{Zn}$ and $\mathrm{Cu}$, respectively.

arc magmas. However, the HIMU average is much higher (150 ppm), consistent with either higher source $\mathrm{Cu}$ concentrations, or a more oxidized source ( $\mathrm{S}$ as $\left.\mathrm{SO}_{4}{ }^{2-}\right)$. Only three HIMU islands are included in the study, but Figure 2D indicates $\mathrm{Cu}$ is compatible during melting even for these islands consistent with their sources having high $\mathrm{Cu}$ concentrations as opposed to being oxidized.
It is possible that the $\mathrm{La} / \mathrm{Yb}$ regression slopes reflect temperature effects on bulk partition coefficients. Le Roux et al. (2011) measured olivine/melt and orthopyroxene/melt partitioning coefficients indicating that $\mathrm{Mn}, \mathrm{Fe}, \mathrm{Co}, \mathrm{Ni}$ and possibly also $\mathrm{Zn}$ become less compatible with increasing temperature but calculated bulk peridotite/melt coefficients suggesting that Fe and $\mathrm{Zn}$ show little temperature dependence, with Mn sub- 


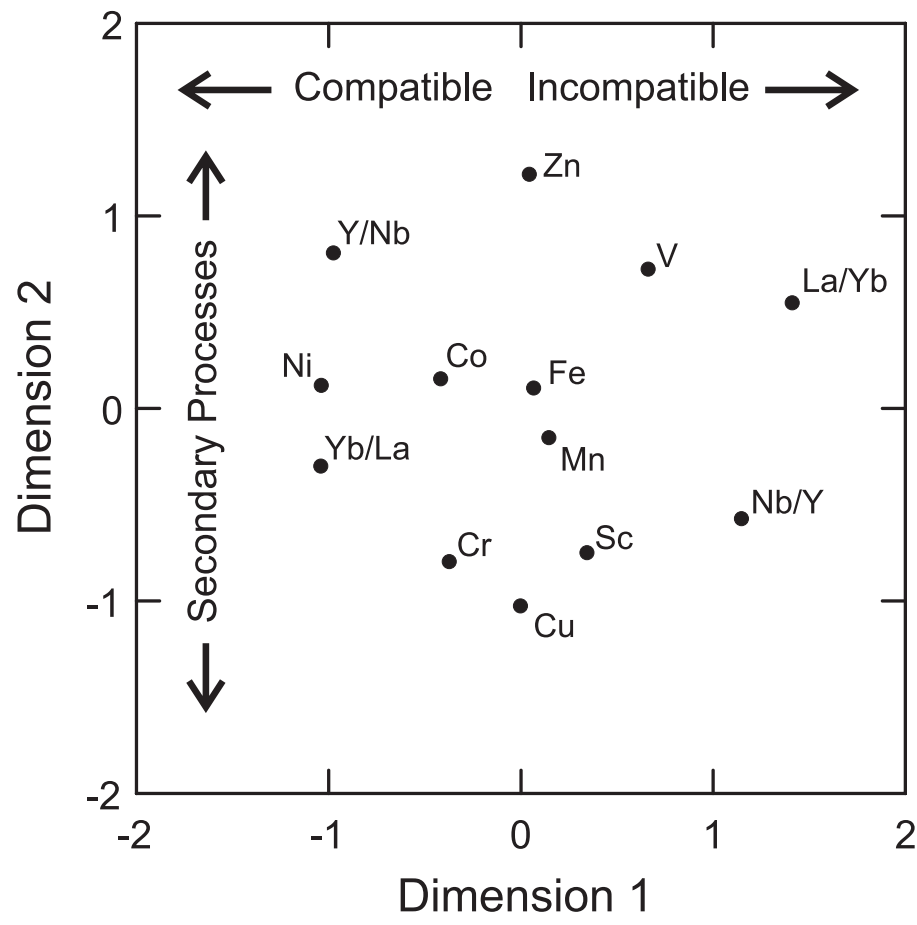

Figure 3. Multidimensional scaling diagram illustrating relationships between transition metal abundances and proxies for the percentage melting $(\mathrm{La} / \mathrm{Yb}$ and $\mathrm{Nb} / \mathrm{Y}$ and their inverses) in primary $(\mathrm{Mg} / \mathrm{Fe}$ wt. \% $\% 1)$ oceanic island basalts. Dimension 1 and Dimension 2 can be thought of as 'map coordinates.' Objects (e.g. two elements) that plot close together will have a high element-versus-element correlation coefficient. Compatible elements (e.g. Ni) plot toward the left whereas less-compatible to modestly incompatible elements plot somewhat to the right along Dimension 1. Some secondary process or processes (e.g. source region compositional variation) causes elements to spread out along Dimension 2. See text for discussion. To produce the diagram, elements and ratios were $z$-scored and a matrix of element (or ratio)-versus-element correlation coefficients were prepared and processed in SYSTAT MDS software using a Kruskal loss function and linear multidimensional scaling. Diagram uses data from Table 1.

tly more compatible, and Co less compatible, with increasing temperature. Assuming that temperature increases with depth, and given the strong positive correlation between $\mathrm{La} / \mathrm{Yb}$ and pressure (Greenough et al. 2005b), lower concentrations for most metals at high $\mathrm{La} / \mathrm{Yb}$ could reflect increased compatibility at higher temperatures. Given the information from Le Roux et al. (2011) for a minor impact of temperature on bulk $\mathrm{D}$ values, the simplest explanation for any metal concentration correlations with $\mathrm{La} / \mathrm{Yb}$ from this study is that they reflect the percentage of melting.

Estimates were made for transition metal concentrations in a primary magma with a $\mathrm{La} / \mathrm{Yb}$ ratio of 10 (Table 2), a value that divides tholeiitic from alkaline OIB (Greenough et al. $2005 \mathrm{a}, \mathrm{b})$ and all islands here are at least subtly alkaline $(\mathrm{La} / \mathrm{Yb}$ $\geq 10$; Fig. 2). The La/Yb-adjusted concentrations were calculated by moving an element's island concentration (Table 1) parallel to the overall $\mathrm{La} / \mathrm{Yb}$ versus element regression slope in Table 2 , to a $\mathrm{La} / \mathrm{Yb}$ value of 10 .

Using these data, a MDS diagram was prepared (not shown) but unlike Figure 3 it reveals a 'random' distribution of the $\mathrm{La} / \mathrm{Yb}$-adjusted transitional metals, none of which plot close to indicators of melting percentage (e.g. La/Yb). Thus, the normalization procedure discussed above removed any clear dependence of metal abundance estimates on the percentage of melting. The compatible behaviour of $\mathrm{Cr}, \mathrm{Ni}$ and

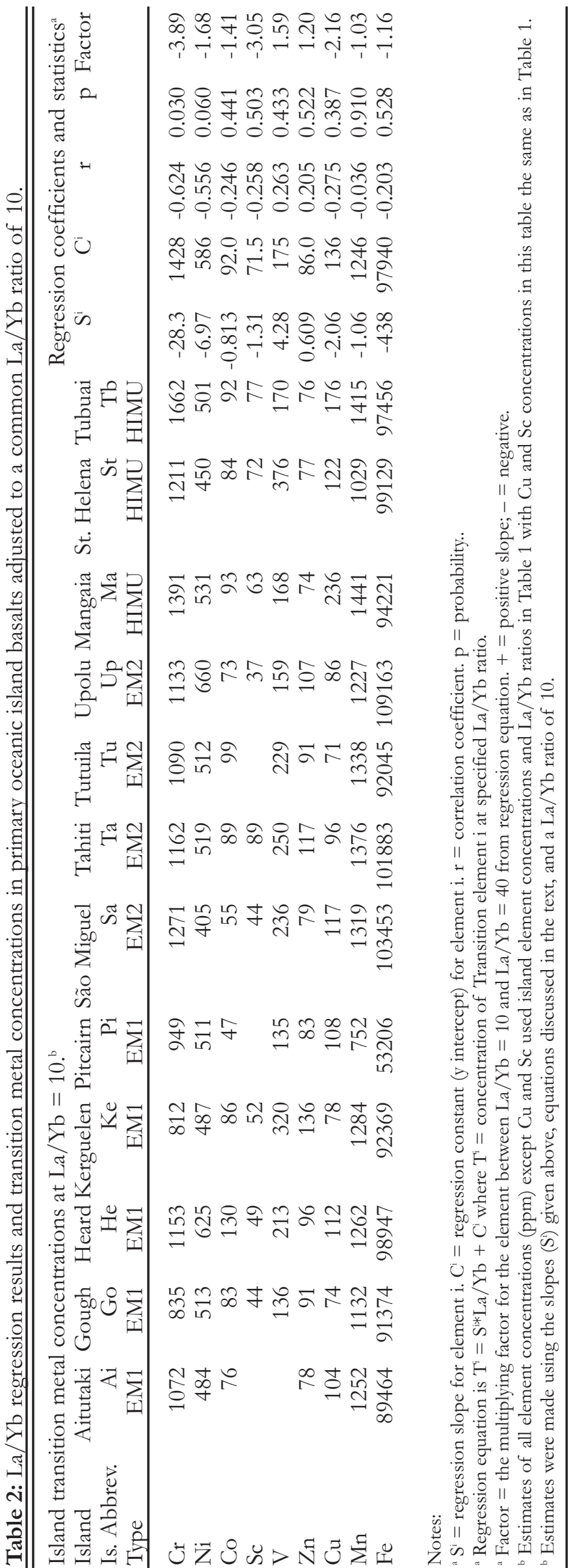



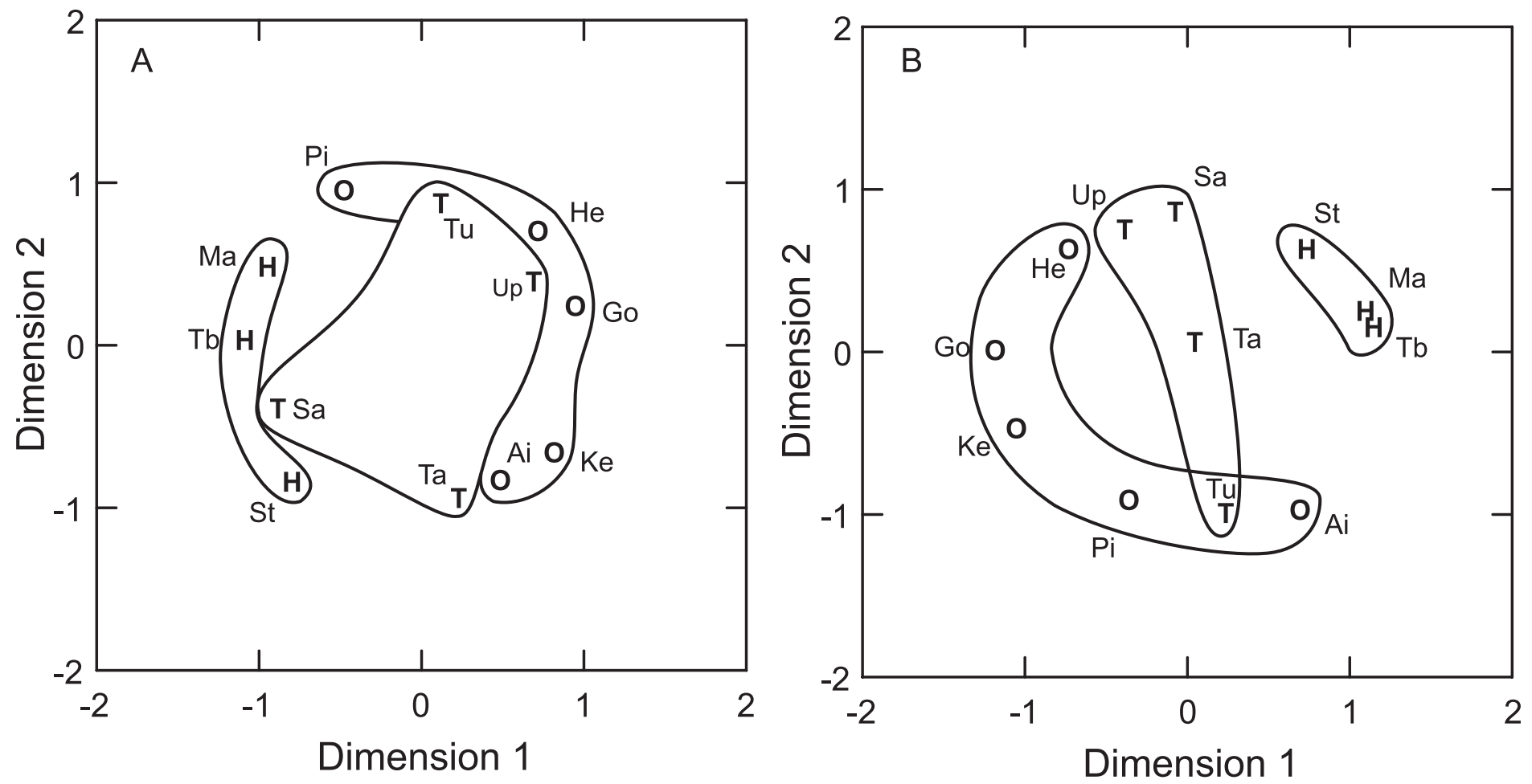

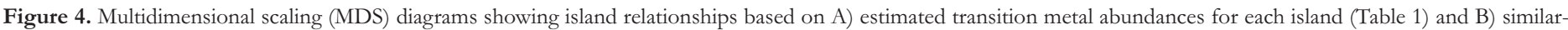

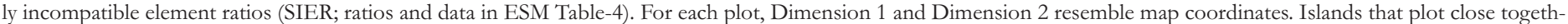

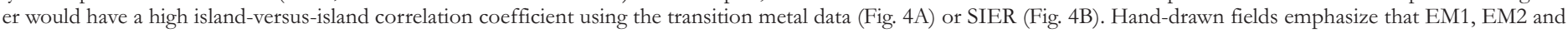

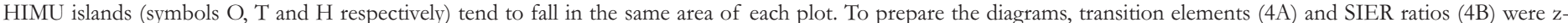

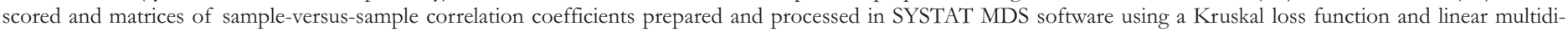

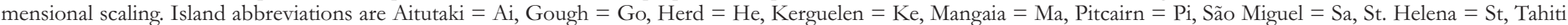
$=\mathrm{Ta}$, Tubuai $=\mathrm{Tb}$, Tutuila $=\mathrm{Tu}, \mathrm{Upolu}=\mathrm{Up}$.

Co during melting means that primary tholeiitic OIB $(\mathrm{La} / \mathrm{Yb}$ $\sim$ 5; e.g. Mauna Loa average, Greenough et al. 2005b) will have higher $\mathrm{Cr}, \mathrm{Ni}$ and $\mathrm{Co}$ concentrations than the alkali basalt examples in this study (extrapolate $\mathrm{Ni}$ and $\mathrm{Cr}$ trends in Fig. 2). The following section looks at patterns in the transition metal data related to mantle component type keeping in mind the impact of melting.

\section{Transition Metals and the Mantle Components}

A problem with analyzing multi-element geochemical data sets using inferential statistics is that it is all too easy to find some element or combination of elements that fortuitously confirms pre-conceived notions about how samples should be related. The advantage of starting the analysis with an exploratory statistical tool such as MDS is that all element data can be used simultaneously to uncover the dominant relationships between samples (islands). In addition, the software does not know one island from another, and patterns that emerge are purely a reflection of relationships in the input data and are unlikely to be fortuitous. Once the dominant relationships have been ascertained, it is possible to use inferential techniques with more confidence to understand the causes of these relationships.

The MDS diagram in Figure 4A shows overall island relationships using all estimated transition metal abundances in primary magmas (Table 1) unadjusted for the percentage of melting. To prepare Figure 4A, Table 1 data were $\mathrm{z}$-scored (each element put on the same scale), a matrix of sample-versus-sample Pearson correlation coefficients calculated, and these data used with linear regression and a Kruskal loss function to yield Figure 4A. As shown, EM1 appears distinct from HIMU but EM2 islands are less distinct and plot between or overlap onto fields for EM1 and HIMU. Another MDS diagram (not shown) was prepared from the La/Yb-adjusted transition metal abundances (Table 2) but it is very similar to Figure 4A. Reasons why the $\mathrm{La} / \mathrm{Yb}$-adjusted and unadjusted data sets lead to similar MDS diagrams include: 1) the percentage of melting impacts the most compatible and most incompatible element concentrations, but some, or most elements are relatively unaffected (neither strongly incompatible or compatible); 2) nearly $80 \%$ of the islands, have somewhat similar $\mathrm{La} / \mathrm{Yb}$ ratios that fall between 20 and 30 and thus these islands formed from similar percentages of melting; 3) 'similarity' between islands was determined using Pearson correlation coefficients; primary basalt from two islands formed from identical source regions but from somewhat different percentages of melting will show different concentrations for many elements, but this does not mean that they will not be highly correlated. In other words the use of correlation coefficients as a distance measure mitigates the impact of the percentage of melting. Due to the fewer assumptions associated with the derivation of the 'primary magma' compositions in Table 1, subsequent discussion focuses on these data.

The organization of islands by component type based on the transition metal data (Fig. 4A) resembles results if similarly incompatible element ratios (SIER) are used to compare islands (Fig. 4B) with MDS methods detailed in Greenough et al. (2007). Elements with similar bulk distribution coefficients 

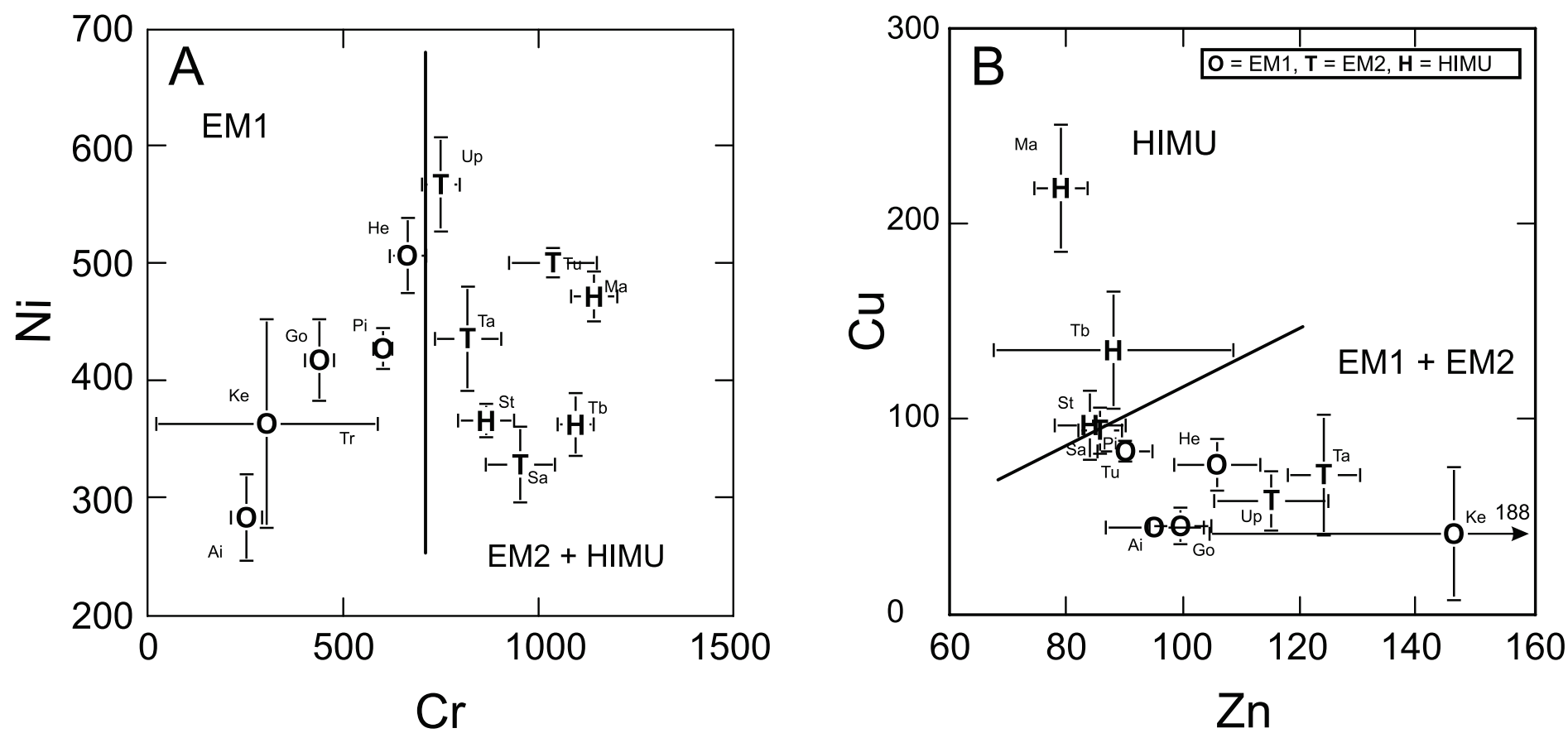

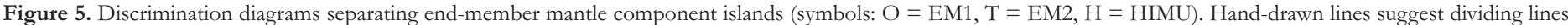

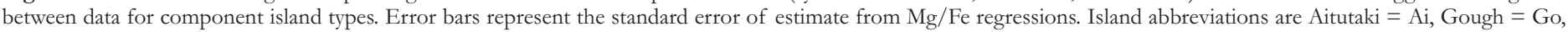

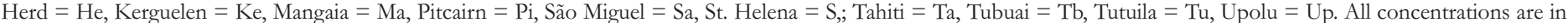
ppm. Plots derived from data in Table 1 with standard error of estimate values given in Electronic Supplementary Materials ESM Table-3.

(i.e. separated by $\leq 10$ elements in the Sun and McDonough (1989) relative incompatibility list) should have ratios in magmas that approach mantle source values, and the ratios will not vary with the percentage of melting. Ratios are also minimally impacted by differentiation. If the ratio for two similarly incompatible elements varies between islands, the variation probably reflects differences in source region composition. The fifty ratios used here (ESM Table-4 which also gives ratio calculation procedures), involving 22 incompatible elements, were identified in Greenough et al. (2005b) as useful for distinguishing OIB mantle components. Figure 4B shows that these SIER separate EM1, EM2 and HIMU basalts but like the transition metals, EM2 tends to be intermediate between EM1 and HIMU. Based on Figure 4A and 4B, it appears that patterns in transition metal abundances are dominantly tied to mantle component type and thus likely related to recycling of lithospheric materials back into the mantle.

Chromium effectively separates EM1 from EM2 and HIMU islands (Fig. 5A). Copper-Zn relationships separate HIMU from EM1 and EM2 (Fig. 5B). Other than Cr, the only elements that tend to distinguish EM1 and EM2 are Fe and possibly Mn. Scandium can also effectively separate EM1 from HIMU. Nickel, Co and V concentrations are similar in all three groups. Thus, the distinctions between the mantle components are subtle and it is only when all data are assessed simultaneously (Fig. 4A) that clear patterns emerge. The situation is similar with SIER where individual ratio-versus-ratio plots do not, in general, unambiguously separate end member islands (Greenough et al. 2005b, 2007) but use of many ratios simultaneously distinguishes the mantle components on MDS plots (Fig. 4B).

\section{Origins of the Mantle Components}

Proposals for origin of the end-member mantle components (HIMU, EM1, EM2, DMM = Depleted MORB mantle, $\mathrm{FOZO}=$ Focal Zone) are well discussed in the literature (Zindler and Hart 1986; Sun and McDonough 1989; Hart et al. 1992; Hofmann 1997; Hilton et al. 1999; Bennett 2003; Hofmann 2003; Jackson and Dasgupta 2008). A popular hypothesis suggests that HIMU sources contain subduction-processed ocean floor basalt (Hofmann 2003; Greenough et al. 2005b, 2007). EM1 and EM2 tend to be ascribed to sediment subduction but the signatures are strongest in basalt that formed from melting subcontinental lithosphere (Hawkesworth et al. 1986; Weaver 1991; Milner and le Roex 1996; Greenough and Kyser 2003). The time of formation of the mantle components is poorly constrained but Said and Kerrich (2010) and Manikyamba and Kerrich (2011) have shown that HIMU existed since the Neoarchean and may still be forming. EM1 appears to be Archean, whereas EM2 may be Proterozoic or younger (Tatsumi 2000; Greenough and Kyser 2003; Greenough et al. 2005b, 2007).

The transition metal-based MDS results (Fig. 4A) show OIB islands group based on mantle component type. Average transition metal concentrations for EM1, EM2 and HIMU (Table 3) are shown on primitive mantle-normalized diagrams in Figure 6. T-tests comparing individual mean compositions of EM1, EM2 and HIMU islands indicate that $\mathrm{Zn}$ is lower in HIMU compared to EM1 ( $p=0.08)$ and EM2 ( $p=0.11)$, supporting hypotheses that HIMU sources have been depleted in chalcophile elements $(\mathrm{Pb}, \mathrm{Zn})$ as a result of element extraction from ocean floor basalt during subduction processing and transfer of these elements to the continental lithosphere (Hofmann 1997, 2003). The model suggests that high-field-strength elements (e.g. U, Th) were not transferred by this process. 


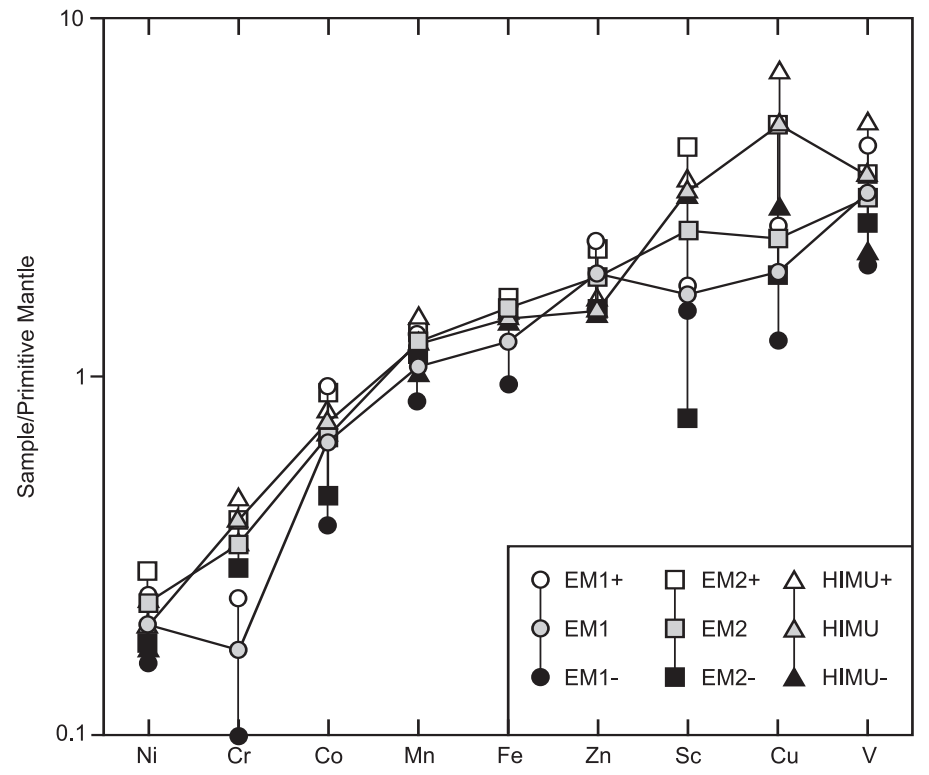

Figure 6. Primitive mantle normalized patterns for averaged primary magma EM1, EM2 and HIMU transition metal concentrations (Table 3). Elements are organized along the $\mathrm{x}$-axis based on average enrichment compared to primitive mantle. Error bars (e.g. EM1+ and EM1-) represent the standard deviation on mean metal concentrations (Table 3) for each island type. Note the log scale on the Y axis. Primitive mantle normalizing values are from McDonough (2003).

However, chalcophile $\mathrm{Cu}$ appears higher in HIMU sources compared to EM1 ( $p=0.12$ ) and EM2 ( $p=0.16$; Fig. 6) perhaps because it was not as efficiently extracted from the ocean floor source as $\mathrm{Zn}$. Chromium tends to have a 3+ charge and it might be predicted that, like other high-field-strength elements (U, Th) it should be enriched in HIMU sources (not transferred to the lithosphere). The t-tests and Figure 6 show that this is the case when comparisons are made with EM1 sources $(p=0.004)$, but EM2 is not distinctive $(p=0.24)$. Similarly, Sc is higher in HIMU compared to EM1 ( $p=0.0006)$. To conclude, comparing EM1 and EM2 transition metal abundances to those in HIMU supports the hypothesis that HIMU represents subduction-processed lithosphere now part of the convecting oceanic mantle.

Nickel, Co, and V are similar in primary magmas from all three types of source regions but t-tests indicate that $\mathrm{Cr}(\mathrm{p}=$ 0.004), Fe (0.05) and Mn (0.13) (Fig. 6) are lower in EM1 compared to EM2 (Fig. 6; Table 3). Assuming that both are sediment signatures superimposed on subcontinental lithosphere and EM1 is Archean and EM2 Proterozoic (or younger), differences in $\mathrm{Cr}, \mathrm{Fe}$ and $\mathrm{Mn}$ could reflect how elements were transferred between the subducting slab and overlying lithosphere. High Archean heat flow resulted in continent-forming melt transfer from the slab whereas cooler Proterozoic processes yielded fluid transfer to the overlying mantle lithosphere in association with the major craton-stitching orogenic events circa 1.8 Ga (Hoffman 1988; Drummond and Defant 1990). Melt transfer may have more efficiently removed $\mathrm{Cr}, \mathrm{Fe}$ and Mn from subducted sediment during the Archean leaving EM1 sources depleted in these elements.

Alternative explanations for differences in $\mathrm{Cr}, \mathrm{Mn}$ and $\mathrm{Fe}$ between EM1 and EM2 include differences in mantle oxidation state or the proportions of garnet and clinopyroxene in source regions. These elements have multiple valence states,
Table 3: Average transition metal concentrations in primary EM1, EM2 and HIMU.

\begin{tabular}{lrrrrrr}
\hline \hline Island & Av. EM1 & SD & Av. EM2 & SD & Av. HIMU & SD \\
\hline Cr & 457 & 180 & 894 & 130 & 1038 & 148 \\
$\mathrm{Ni}$ & 399 & 83 & 458 & 102 & 400 & 62 \\
$\mathrm{Co}$ & 70 & 30 & 71 & 22 & 79 & 6.1 \\
$\mathrm{Sc}$ & 27 & 2 & 41 & 29 & 53 & 2.7 \\
$\mathrm{~V}$ & 266 & 98 & 259 & 40 & 296 & 117 \\
$\mathrm{Zn}$ & 108 & 23 & 105 & 18 & 84 & 4.5 \\
$\mathrm{Cu}$ & 58 & 20 & 73 & 15 & 150 & 62 \\
$\mathrm{Mn}$ & 1117 & 219 & 1305 & 66 & 1281 & 230 \\
$\mathrm{Fe}$ & 7722817194 & 974614971 & 91015 & 2597
\end{tabular}

Notes: Number of islands for EM1, EM2 and HIMU, most elements $=5$, 4 , and 3 .

Exceptions: Sc $=3$ EM1 and 3 EM2; and V $=4$ EM1 due to no data for some islands.

All concentrations are in $\mathrm{ppm}$ of the metal.

and magmatic concentrations may reflect increasing oxidation (e.g. Holland 1984; Rouxel et al. 2005) of subducted sediment between the Archean (EM1) and Proterozoic (EM2). Le Roux et al. (2010) theorized that high source region $f\left(\mathrm{O}_{2}\right)$ should result in low magmatic $\mathrm{Zn} / \mathrm{Fe}$ and high $\mathrm{Fe} / \mathrm{Mn}$. Lee et al. (2010) looked at $\mathrm{Zn} / \mathrm{Fe}$ in more detail and concluded that primitive arc magmas, primitive MORB, and mantle peridotite have $\mathrm{Zn} / \mathrm{Fe}^{*} 10^{4}$ ratios between 8 and 11 consistent with an upper mantle $f\left(\mathrm{O}_{2}\right)$ value between FMQ-1 and FMQ+1 (log units) as found by other studies (Lee et al. 2005, 2012; Mallmann and O'Neill 2009). Our Zn/Fe ratios (mean of all values, Table $1=11.9$; Fig. 7) are identical to those for OIB reported by Le Roux et al. (2010; $\mathrm{Zn} / \mathrm{Fe} * 10^{4}=9.6-13.9$ ) though Kerguelen and Pitcairn (17 and 19) are high. The mean for EM1 (14.4) is higher than the mean for EM2 (10.7; p = 0.08 ) and HIMU (9.2) potentially consistent with lower $f\left(\mathrm{O}_{2}\right)$ in EM1 sources. However, mean Fe/Mn ratios for EM1, EM2 and HIMU are similar (68, 75 and 73, respectively) and assuming restricted variability in mantle $f\left(\mathrm{O}_{2}\right)$ (e.g. Mallmann and O’Neill 2009; Lee et al. 2010, 2012), high Zn/Fe in EM1 does not appear related to oxidation. Following arguments in Le Roux et al. (2010) to explain higher $\mathrm{Zn} / \mathrm{Fe}$ in OIB compared to MORB, it may be that EM1 sources have high $\mathrm{Zn} / \mathrm{Fe}$, or be more garnet- and/or clinopyroxene-rich compared with HIMU and EM2.

\section{Comments on Metallogenesis}

A few $(<20)$ large intrusions supply most of the world's $\mathrm{Ni}$, Co, Cr, and PGE (platinum-group elements) (e.g. Best 2003, p. 331). They may be ore-bearing because they formed from magmas with 'compatible' element concentrations maximized by high percentages of melting, or other factors (e.g. sulphur fugacity) may have impacted deposit formation (e.g. Lee 1996; Naldrett 2005; Mungall and Naldrett 2008). They are noritic (Kerrich et al. 2005) and bear extreme EM1-like Ba/La and $\mathrm{Rb} / \mathrm{Ba}$ signatures (Zhang et al. 2008; Said and Kerrich 2010; Greenough et al. 2011) that contrast with uneconomic intrusions bearing HIMU and EM2 signatures (Zhang et al. 2008). The regression results (Table 2) predict high $\mathrm{Cr}, \mathrm{Ni}$ and $\mathrm{Co}$ $(1300,570$ and 90 ppm, respectively) in high \% melting, rift or 

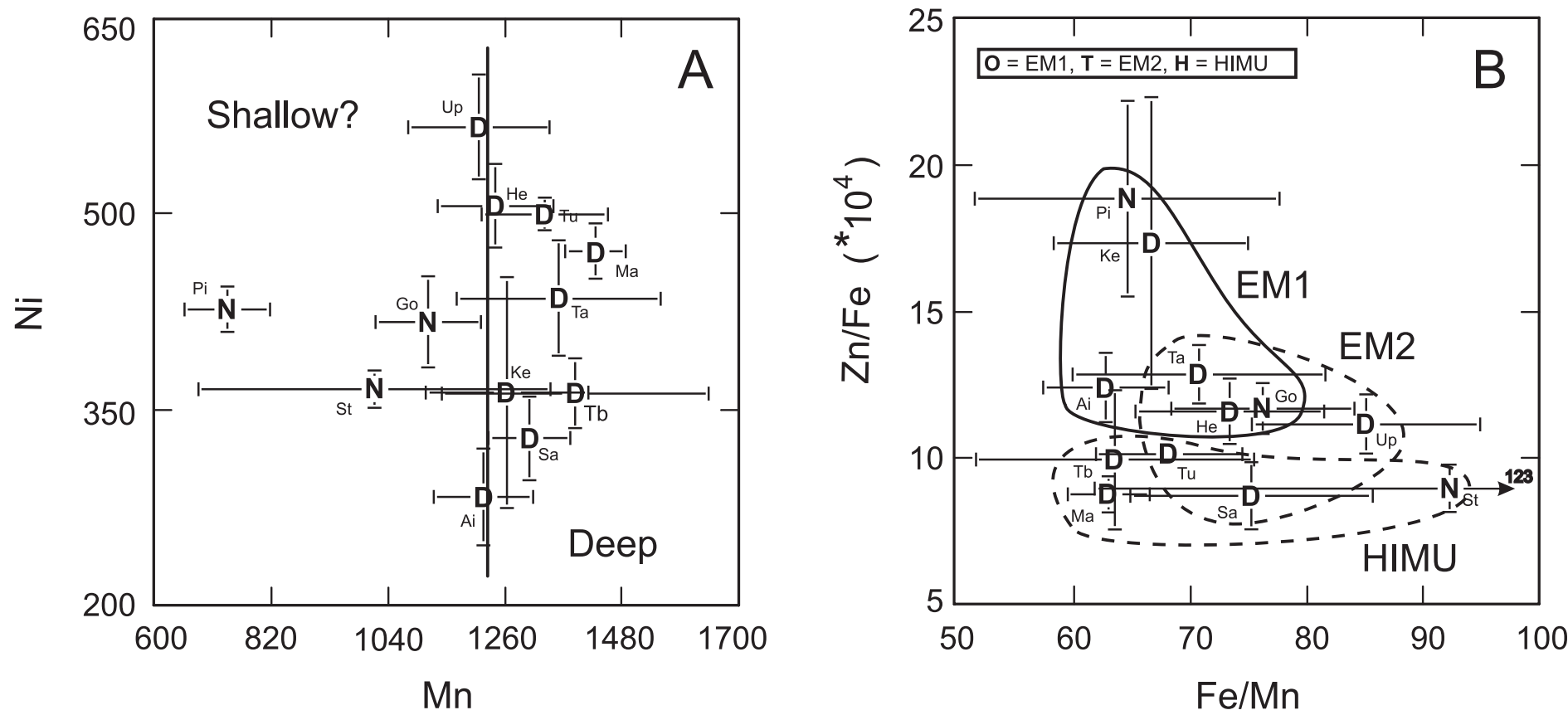

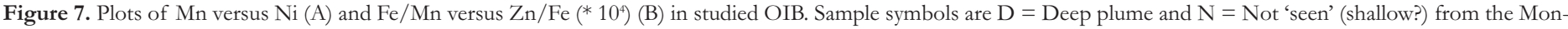

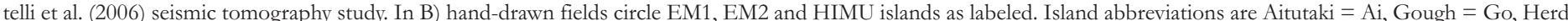

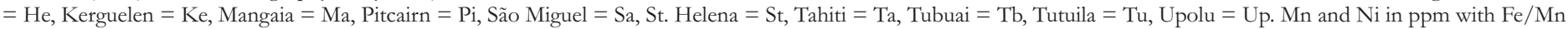

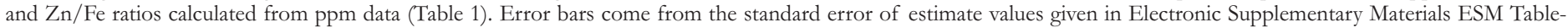

superplume magmas (e.g. $\mathrm{La} / \mathrm{Yb}=2$ ). The $\mathrm{Cr}$ and $\mathrm{Ni}$ values resemble those in picritic Deccan basalt $(1500$ and $665 \mathrm{ppm}$, respectively) and olivine-rich Karroo basalt (960 and 800 ppm, respectively; primary magmas; Basaltic Volcanism Study Project 1981, p. 409-432). Thus, our results confirm that for Ni, Cr and Co, economic potential is enhanced by a high $\%$ melting but they do not support EM1 sources having anomalously high concentrations of these elements. In the case of Cr, EM1 sources may have lower concentrations than either HIMU or EM2. Thus other EM1 characteristics, such as sulphur availability or solubility and/or magma oxygen fugacity may lead to element scavenging and concentration to form ore deposits.

\section{Mineralogical and Lithological Composition of the Mantle}

Elements discussed here have been used to test for core-mantle interaction, a sediment contribution to the sources of some enriched-mantle component magmas, and olivine-free (pyroxenite) mantle source lithologies. Sobolev et al. (2005) argued that high $\mathrm{Ni}$ content in Hawaiian olivine reflects precipitation from high Ni magmas generated from low melting point eclogite (recycled basaltic oceanic crust) after reaction with peridotite to produce pyroxenite. Pyroxenite melts variably mixed with peridotite melts yielding magmas with high $\mathrm{Ni}$ contents because olivine-free pyroxenite would have a lower bulk crystal/liquid partitioning coefficient than magmas from sources bearing olivine. Sobolev et al. (2007) expanded on the model. Gurenko et al. (2009) tested it using Canary Islands basalt where some rocks have extreme HIMU signatures that should show the high-Ni signature well. Extreme HIMU signatures, reflected in high ${ }^{206} \mathrm{~Pb} /{ }^{204} \mathrm{~Pb}$ and ${ }^{207} \mathrm{~Pb} /{ }^{204} \mathrm{~Pb}$ isotopic ratios are commonly ascribed to source enrichment in aged, recycled, oceanic basaltic crust that will form eclogite at pressure. Using modified equations by Sobolev et al. (2007) to predict the relative proportions of peridotite and pyroxenite involved in melting, Gurenko et al. (2009) concluded that the isotopically most extreme HIMU Canary Islands samples come from peridotite, as opposed to pyroxenite-rich sources. Herzberg (2011) used existing experimental major element data, Ni and Mn data, numerical models for predicting source mineralogy/ lithology, magma composition and olivine compositions, and a solid-state, recycled crust-mantle peridotite reaction model for production of pyroxenite (different from Sobolev et al. 2005, 2007 and Gurenko et al. 2009 cited above) to conclude that Ni, $\mathrm{Ca}, \mathrm{Mn}$, and $\mathrm{Fe} / \mathrm{Mn}$ data for olivine phenocrysts from Hawaii and the Canary Islands support the pyroxenite source model.

Our results do not show any clear difference in the Ni content of magmas from each of the mantle components and thus provide no support for the idea that HIMU (eclogite/ pyroxenite-rich) sources produce high-Ni magmas. Similarly, Sobolev et al. (2007) predicted that pyroxenite-derived melts will have higher $\mathrm{Fe} / \mathrm{Mn}$ ratios and higher Si than peridotitederived melts. Although our $\mathrm{Fe} / \mathrm{Mn}$ ratio for St. Helena is high, the other two HIMU islands have among the lowest $\mathrm{Fe} / \mathrm{Mn}$ ratios (Table 1). A study of the major element composition of end-member mantle component OIB (Jackson and Dasgupta 2008) concluded that HIMU islands have lower Si contents and the low Si does not appear related to high-pressure melting. Thus, overall, these observations do not support a pyroxenite or olivine-free-source model.

Wang and Gaetani (2008) did Ni partitioning coefficient experiments and concluded that reaction of an eclogitederived melt with olivine (peridotite) can yield Si-enriched melts with moderate $\mathrm{Ni}$ contents that precipitate high-Ni olivine. They argued that an olivine-free 'hybrid' pyroxenite source, as proposed by Sobolev et al. (2005), is not required to 
explain high-Ni contents in Hawaiian lavas. Gurenko et al. (2009) argued that the Wang and Gaetani (2008) results cannot account for variations in $\mathrm{Fe} / \mathrm{Mn}$ ratios but as noted above, there is no clear support for olivine-free sources from $\mathrm{Fe} / \mathrm{Mn}$ ratios. Humayun et al. (2004) and Qin and Humayun (2008) recognized the potential utility of $\mathrm{Fe} / \mathrm{Mn}$ ratios for testing hypotheses on the origin of OIB but were concerned about the analytical integrity of existing data sets for resolving arguments. Their high-precision $\mathrm{Fe}$ and $\mathrm{Mn}$ measurements were used to argue for high Fe in OIB. This was ascribed to core-mantle interaction but they could not rule out the possibility that mantle pyroxenite (model by Sobolev et al. 2005, 2007) influences or controls ratios. The seven samples they analyzed from Tahiti (EM2) have an average $\mathrm{Fe} / \mathrm{Mn}$ ratio of 67 (ratio here $=71)$ and the three from St. Helena (HIMU) gave a low average ratio (57) compared to what we obtained (92; Table 1) but their St. Helena ratio resembles the ratios of other HIMU-type islands studied here (Mangaia = 63; Tubiai $=64$; Table 1). Perhaps pyroxenite is important in the generation of HIMU OIB, but based on the predictions from the afore-mentioned experiments, our data do not appear to support the hypothesis because critical elements $(\mathrm{Ni}, \mathrm{Fe}, \mathrm{Mn})$ and ratios $(\mathrm{Fe} / \mathrm{Mn})$ are not substantially different for other types of OIB (EM1; EM2). A caveat is that EM1 and EM2 may represent other types of pyroxenite sources modified by the addition of subducted sediment or by addition of metasomatic fluids bearing a subducted sediment signature.

Le Roux et al. (2010) drew attention to the potential significance of high $\mathrm{Zn} / \mathrm{Fe}$ ratios in some OIB compared to $\mathrm{MORB}$, and argued that because ratios cannot be fractionated during peridotite melting, either some OIB originates from peridotite sources with high $\mathrm{Zn} / \mathrm{Fe}$, or it comes from lithologies (e.g. eclogite) with bulk $\mathrm{Zn} / \mathrm{Fe}$ (solid source/melt) partitioning coefficients less than one. A follow-up study (Le Roux et al. 2011) measured mineral/melt partitioning coefficients for $\mathrm{Mn}, \mathrm{Co}, \mathrm{Ni}$ and $\mathrm{Zn}$ in olivine, orthopyroxene, and clinopyroxene, and integrated published results for garnet. These data were used to predict $\mathrm{Mn} / \mathrm{Fe}, \mathrm{Zn} / \mathrm{Fe}, \mathrm{Mn} / \mathrm{Zn}$ and $\mathrm{Co} / \mathrm{Fe}$ ratio behaviour during partial melting of primitive mantle peridotite, MORB-like eclogite and mixtures of the two. The modeling yielded maximum $\mathrm{Zn} / \mathrm{Fe}$ and minimum $\mathrm{Ni} / \mathrm{Co}$ and $\mathrm{Co} / \mathrm{Fe}$ ratios for pure peridotite melting and they concluded that many OIB have element ratios that deviate from what is predicted from melting pure peridotite sources. Issues are that $\mathrm{Zn} / \mathrm{Fe}$ ratios predict that MORB dominantly have peridotite sources, but they have $\mathrm{Ni} / \mathrm{Co}$ and $\mathrm{Co} / \mathrm{Fe}$ that imply a substantial eclogite component in their sources and $\mathrm{Ni} / \mathrm{Co}$ values suggest more eclogite than in most OIB sources (Le Roux et al. 2011, their figure 7). Comparing our data with their modeling results, many of our end-member islands, including all HIMU have $\mathrm{Zn} / \mathrm{Fe}$ that supports a pure peridotite source. A significant eclogite component $(\geq 30 \%)$ is implied using our $\mathrm{Ni} / \mathrm{Co}$ and $\mathrm{Co} / \mathrm{Fe}$ ratios and EM1 and EM2 islands tend to have a higher eclogitic percentage than HIMU islands. Balta et al. (2011) did melting experiments on peridotite at $3 \mathrm{GPa}$ under hydrous conditions and demonstrated that $\mathrm{Mn}$ can be compatible in garnet and that solid/liquid partitioning coefficients are impacted by temperature and melt composition. These observations predict the potential for large variations in magma Mn content and $\mathrm{Fe} / \mathrm{Mn}$ ratios that only involve peri- dotite melting. The study demonstrates the challenges of modeling (e.g. Le Roux et al. 2011), where there are many variables that can impact results. Similarly, isotopes and incompatible element ratios tell us that the end member OIB sources are chemically different and that assumptions about constant transition metal concentrations for peridotite and eclogite may not be valid. Our results suggest that the end-member mantle components are apparently distinct in terms of some transition metal abundances. Thus modeling of these elements to predict the relative importance of eclogite versus peridotite in sources will apparently require better information on source chemical composition.

\section{Implications for Core-Mantle Interaction}

Estimates by McDonough (2003) suggest that 93\% to 50\% of the Earth's Ni, Co, Fe, Cu, and $\mathrm{Cr}$ occur in the core. Thus 'mantle plume' basalt sources could be enriched in these elements if they exchanged matter with the core. The seismic tomography techniques of Montelli et al. $(2004,2006)$ purport to see $\sim 35$ narrow plume-like structures, most originating at the base of the lower mantle with only two confined to the upper mantle. Plumes of shallow origin cannot have interacted with the core. Table 1 shows depths-of-origin for plumes studied here (Montelli et al. 2004, 2006) and most originate from $\sim 2800 \mathrm{~km}$ (base of the lower mantle). Islands Tubuai and Tahiti occur on different hot-spot traces but within the same low-velocity anomaly (see Table 1 notes). Plumes associated with Gough, St. Helena and Pitcairn islands were not 'seen' possibly reflecting inadequacies in the distribution of epicentres and seismic stations (Kerr 2003; Montelli et al. 2004), the plumes are extinct, or they are so narrow they escaped imaging. Assuming that un-imaged plumes are shallow, inspection of the transition metal-based MDS diagram (Fig. 4A) reveals that the three islands (symbols; St, Go and Pi) plot randomly. With the exception of Mn (Fig. 7A), none of the elements separate un-imaged (shallow?) plumes from imaged deep-plume islands. Although Mn concentrations are higher in islands associated with imaged deep plumes, core-mantle interaction is unlikely to control mantle $\mathrm{Mn}$ because the core has $10 \%$ of the planet's Mn budget and lower concentrations $(0.03$ wt. $\%)$ than in the mantle $(0.10$ wt. \%; McDonough 2003). Humayun et al. (2004) proposed that high $\mathrm{Fe} / \mathrm{Mn}$ in Hawaiian OIB compared to MORB and Iceland basalt (a 'shallow' plume; Montelli et al. 2006) suggests core-mantle interaction by the Hawaiian plume. However, islands underlain by deep plumes do not show high $\mathrm{Fe} / \mathrm{Mn}$ ratios (Fig. 7B).

Our results suggest that 'incompatible' transition metal abundances correlate with mantle component source type (Fig. 4) and thus dominantly reflect recycling of lithosphere. Tungsten, $\mathrm{Tl}$ and Os isotopic studies support recycling of lithospheric materials back into the mantle, with little or no evidence for core-mantle interaction (Schaefer et al. 2002; Scherstén et al. 2004; Brandon and Walker 2005; Nielsen et al. 2006, Willbold et al. 2009; Nebel et al. 2010). Thus our results support arguments against core-mantle interaction and suggest that transition metal concentrations are probably controlled by lithospheric recycling. 


\section{SUMMARY COMMENTS AND CONCLUSIONS}

Radiogenic and stable isotopes along with incompatible trace element ratios firmly establish the existence of the mantle components (Zindler and Hart 1986; Weaver 1991; Eiler et al. 1997; Hofmann 2003; Greenough et al. 2007). Because the vast amount of the previous work is based on lithophile elements, the components are unlikely to be products of processes involving the core. Given the importance of subduction today and through Earth history, the mantle components probably reflect lithospheric recycling processes (ibid.). Beyond these generalizations, detailed information on the composition of the components is lacking and therefore their origin, and what they represent (e.g. sediment, ocean floor basalt, continental crust, etc.) remains speculative. Results here suggest that the first-row transition metals in OIB also reflect these lithospheric recycling processes because they dominantly correlate with well-established information on component type for the endmember islands used in the study. Chromium, $\mathrm{Zn}, \mathrm{Cu}$, and $\mathrm{Fe}$ appear particularly correlated with component type but most elements make contributions to distinguishing one or more of the components. Three of these ( $\mathrm{Mn}, \mathrm{Zn}$ and $\mathrm{Sc}$ ) are probably not important core constituents. Although results are not shown, discriminant analysis confirms that various combinations of $\mathrm{Cr}, \mathrm{Ni}, \mathrm{Co}, \mathrm{Fe}, \mathrm{Cu}$, and $\mathrm{V}$ (important core constituents; McDonough 2003) separate islands by component type. Of these elements, Ni makes the least contribution to separation because average concentrations are similar for each component type. Unless core-mantle interaction resulted in somewhat uniform $\mathrm{Ni}$ concentrations in all island-forming plumes it is not obvious that this lack of relationship between $\mathrm{Ni}$ and component type provides any substantial support for core-mantle interaction. The work by Humayun et al. (2004) implies that element ratios may be more sensitive tests of core-mantle interaction. Accordingly, 21 least compatible and more compatible element ratios were calculated from elements that are adjacent, or within three elements of one another in the list (moderately incompatible to most compatible: $\mathrm{Zn}, \mathrm{Mn}$, $\mathrm{V}, \mathrm{Fe}, \mathrm{Co}, \mathrm{Cu}, \mathrm{Sc}, \mathrm{Ni}$, and $\mathrm{Cr}$ ). These ratios were used with MDS to compare the 'similarity' of islands and, like element concentrations, they separate EM1 from HIMU but show EM2 as intermediate. The plot is not shown because it is essentially the same as obtained with element concentrations (Fig. 4A). Although the results here do not preclude core-mantle interaction, the simplest conclusion is that, apart from percentage melting and differentiation, the dominant controls on first-row transition metals in OIB are the processes responsible for forming the mantle components.

\section{ACKNOWLEDGEMENTS}

Ideas for derivation of transition metal abundances in primary OIB magmas stemmed from a study of French Polynesia basalt with J. Dostal. MacKenzie refined methods in a B.Sc. Honours thesis at University of British Columbia, Okanagan. J.B. Balta provided a helpful review of an early version of the manuscript. Reviews by C.-T.A. Lee and an anonymous reviewer led to numerous improvements. R. Corney did the drafting. This work was funded by a NSERC Discovery grant to JDG and made possible by the GEOROC data base.

\section{REFERENCES}

Allègre, C.J., Schiano, P., and Lewin, E., 1995, Differences between oceanic basalts by multitrace element ratio topology: Earth and Planetary Science Letters, v. 129, p. 1-12, http://dx.doi.org/10.1016/0012-821X(94)00235-Q.

Balta, J.B., Asimow, P.D., and Mosenfelder, J.L., 2011, Manganese partitioning dur- ing hydrous melting of peridotite: Geochimica et Cosmochimica Acta, v. 75, p. 5819-5833, http://dx.doi.org/10.1016/j.gca.2011.05.026.

Basaltic Volcanism Study Project, 1981, Basaltic Volcanism on the Terrestrial Planets: Pergamon Press Inc., New York, 1286 p.

Bennett, V.C., 2003, Compositional evolution of the mantle, in Carlson, R.W., ed. Volume 2: The Mantle and Core, Treatise on Geochemistry: Elsevier-Pergamon, Oxford, p. 493-519, http://dx.doi.org/10.1016/B0-08-043751-6/020132

Best, M.G., 2003, Igneous and Metamorphic Petrology, 2nd Edition: Blackwell Science Ltd., Malden, MA, USA, 729 p.

Borg, I., and Groenen, P., 1997, Modern Multidimensional Scaling, Theory and Applications: Springer-Verlag, New York, 472 p., http://dx.doi.org/10.1007/ 978-1-4757-2711-1.

Brandon, A.D., and Walker, R.J., 2005, The debate over core-mantle interaction: Earth and Planetary Science Letters, v. 232, p. 211-225, http://dx.doi.org/ 10.1016/j.epsl.2005.01.034.

Drummond, M.S., and Defant, M.J., 1990, A model for trondhjemite-tonalite-dacite genesis and crustal growth via slab melting: Archean to modern comparisons: Journal of Geophysical Research, v. 95, p. 21503-21521, http://dx.doi.org/ 10.1029/JB095iB13p21503.

Eiler, J.M., Farley, K.A., Valley, J.W., Hauri, E.H., Craig H., Hart, S.R., and Stolper, E.M., 1997, Oxygen isotope variations in ocean island basalt phenocrysts: Geochimica et Cosmochimica Acta, v. 61, p. 2281-2293, http://dx.doi.org/ 10.1016/S0016-7037(97)00075-6.

Greenough, J.D., and Kyser, T.K., 2003, Contrasting Archean and Proterozoic lithospheric mantle: Isotopic evidence from the Shonkin Sag sill (Montana): Contributions to Mineralogy and Petrology, v. 145, p. 169-181, http://dx.doi.org/10.1007/s00410-002-0435-9.

Greenough, J.D., Dostal, J., and Mallory-Greenough, L.M., 2005a, Oceanic Island Volcanism I: Mineralogy and Petrology: Geoscience Canada, v. 32, p. 29-45.

Greenough, J.D., Dostal, J., and Mallory-Greenough, L.M., 2005b, Oceanic Island Volcanism II: Mantle Processes: Geoscience Canada, v. 32, p. 77-90.

Greenough, J.D., Dostal, J., and Mallory-Greenough, L.M., 2007, Incompatible element ratios in French Polynesia basalts: describing mantle component fingerprints: Australian Journal of Earth Sciences, v. 54, p. 947-958, http://dx.doi.org/10.1080/08120090701488271.

Greenough, J.D., Kamo, S.L., Theny, L., Crowe, S.A., and Fipke, C., 2011, High precision $\mathrm{U}-\mathrm{Pb}$ age and geochemistry of the mineralized (Ni-Cu-Co) Suwar intrusion, Yemen: Canadian Journal of Earth Sciences, v. 48, p. 495-514, http://dx.doi.org/10.1139/E10-067.

Gurenko, A.A., Sobolev, A.V., Hoernle, K.A., Hauff, F., and Schmincke, H.-U., 2009, Enriched, HIMU-type peridotite and depleted recycled pyroxenite in the Canary plume: A mixed-up mantle: Earth and Planetary Science Letters, v. 277, p. 514-524, http://dx.doi.org/10.1016/j.epsl.2008.11.013.

Hart, S.R., Hauri, E.H., Oschmann, L.A., and Whitehead, J.A., 1992, Mantle plumes and entrainment: Isotopic evidence: Science, v. 256, p. 517-520, http://dx.doi.org/10.1126/science.256.5056.517.

Hawkesworth, C.J., Mantovani, M.S.M., Tavlor, P.N., and Palacz, Z., 1986, Evidence from the Parana of south Brazil for a continental contribution to Dupal basalts: Nature, v. 322, p. 356-359, http://dx.doi.org/10.1038/322356a0.

Herzberg, C., 2011, Identification of source lithology in the Hawaiian and Canary Islands: Implications for origins: Journal of Petrology, v. 52, p. 113-146, http://dx.doi.org/10.1093/petrology/egq075.

Hilton, D.R., Grönvold, K., Macpherson, C.G., and Castillo, P.R., 1999, Extreme ${ }^{3} \mathrm{He} /{ }^{4} \mathrm{He}$ ratios in northwest Iceland: constraining the common component in mantle plumes: Earth and Planetary Science Letters, v. 173, p. 53-60, http://dx.doi.org/10.1016/S0012-821X(99)00215-0.

Hoffman, P.F., 1988, United plates of America, the birth of a craton: Early Proterozoic assembly and growth of Laurentia: Annual Reviews Earth and Planetary Sciences, v. 16, p. 543-603, http://dx.doi.org/10.1146/ annurev.ea.16.050188.002551.

Hofmann, A.W., 1997, Mantle geochemistry: the message from oceanic volcanism: Nature, v. 385, p. 219-229, http://dx.doi.org/10.1038/385219a0.

Hofmann, A.W., 2003, Sampling mantle heterogeneity through oceanic basalts: isotopes and trace elements, in Carlson, R.W., ed., Volume 2: The Mantle and Core, Treatise on Geochemistry: Elsevier-Pergamon, Oxford, p. 1-44, http://dx.doi.org/10.1016/B0-08-043751-6/02123-X.

Holland, H.D., 1984, The Chemical Evolution of the Atmosphere and Oceans: Princeton University Press, Princeton, NJ, $582 \mathrm{p}$

Humayun, M., Qin, L., and Norman, M.D., 2004, Geochemical evidence for excess iron in the mantle beneath Hawaii: Science, v. 306, p. 91-94, http://dx.doi.org/ 10.1126/science.1101050.

Jackson, M.G., and Dasgupta, R., 2008, Compositions of HIMU, EM1, and EM2 from global trends between radiogenic isotopes and major elements in oceanic island basalts: Earth and Planetary Science Letters, v. 276, p. 175-186, http://dx.doi.org/10.1016/j.epsl.2008.09.023 
Kay, R.W., and Gast, P.W., 1973, The rare earth content and origin of alkali-rich basalts: The Journal of Geology, v. 81, p. 653-682, http://dx.doi.org/10.1086/ 627919

Kerr, R.A., 2003, Mantle plumes both tall and short?: Science, v. 302, p. 1643, http://dx.doi.org/10.1126/science.302.5651.1643.

Kerrich, R., Goldfarb, R.J., and Richards, J.P., 2005, Metallogenic provinces in an evolving geodynamic framework: Economic Geology 100th Anniversary Volume, p. 1097-1136.

Keshav, S., Gudfinnsson, G.H., Sen, G., and Fei, Y., 2004, High-pressure melting experiments on garnet clinopyroxenite and the alkalic to tholeiitic transition in ocean-island basalts: Earth and Planetary Science Letters, v. 223, p. 365-379, http://dx.doi.org/10.1016/j.epsl.2004.04.029.

Keshav, S., Bizimis, M., Gudfinnsson, G.H., Sen, G., and Fei, Y., 2006, Response to the comment by M. Lustrino on "High-pressure melting experiments on garnet clinopyroxenite and the alkalic-tholeiitic transition in ocean-island basalts" by Keshav et al. [Earth and Planetary Science Letters, v. 223, p. 365-379 (2004)] Earth and Planetary Science Letters, v. 241, p. 997-999, http://dx.doi.org/ 10.1016/j.epsl.2005.10.023.

Kogiso, T., Hirschmann, M.M., and Frost, D.J., 2003, High-pressure partial melting of garnet pyroxenite: possible mafic lithologies in the source of ocean island basalts: Earth and Planetary Science Letters, v. 216, p. 603-617, http://dx.doi.org/10.1016/S0012-821X(03)00538-7.

Lee, C.A., 1996, A review of mineralization in the Bushveld Complex and some other Layered Intrusions, in Cawthorn, R.G., ed., Layered Intrusions: Elsevier, NY, p. 103-145, http://dx.doi.org/10.1016/S0167-2894(96)80006-6.

Lee, C.-T.A., Leeman, W.P., Canil, D., and Li, Z.-X.A., 2005, Similar V/Sc systematics in MORB and arc basalts: Implications for the oxygen fugacities of their mantle source regions: Journal of Petrology, v. 46, p. 2313-2336, http://dx.doi.org/10.1093/petrology/egi056.

Lee, C.-T.A., Luffi, P., Le Roux, V., Dasgupta, R., Albaréde, F, and Leeman, W.P., 2010, The redox state of arc mantle using Zn/Fe systematics: Nature, v. 468, p. 681-685, http://dx.doi.org/10.1038/nature09617.

Lee, C.-T.A., Luffi, P., Chin, E.J., Bouchet, R., Dasgupta, R., Morton, D.M., Le Roux, V., Yin, Q.-z., and Jin, D., 2012, Copper systematics in arc magmas and implications for crust-mantle differentiation: Science, v. 336, p. 64-68, http://dx.doi.org/10.1126/science.1217313.

Le Roux, V., Lee, C.-T.A., and Turner, S.J., 2010, Zn/Fe systematics in mafic and ultramafic systems: Implications for detecting major element heterogeneities in the Earth's mantle: Geochimica et Cosmochimica Acta, v. 74, p. 2779-2796, http://dx.doi.org/10.1016/j.gca.2010.02.004.

Le Roux, V., Dasgupta, R., and Lee, C.-T.A., 2011, Mineralogical heterogeneities in the Earth's mantle: Constraints from $\mathrm{Mn}, \mathrm{Co}, \mathrm{Ni}$ and $\mathrm{Zn}$ partitioning during partial melting: Earth and Planetary Science Letters, v. 307, p. 395-408, http://dx.doi.org/10.1016/j.epsl.2011.05.014.

Lustrino, M., 2006, Comment on "High-pressure melting experiments on garnet clinopyroxenite and the alkalic to tholeiitic transition in ocean-island basalts" by Keshav et al. [Earth and Planetary Science Letters, v. 223 (2004), p. 365-379]: Earth and Planetary Science Letters, v. 241, p. 993-996, http://dx.doi.org/ 10.1016/j.epsl.2005.10.024.

MacKenzie, K., 2008, A New Perspective on the Core Mantle Interaction Debate: Unpublished B.Sc. Honors Thesis, University of British Columbia - Okanagan, BC, $29 \mathrm{p}$.

Mallmann, G., and O'Neill, H.St.C., 2009, The crystal/melt partitioning of V during mantle melting as a function of oxygen fugacity compared with some other elements (Al, P, Ca, Sc, Ti, Cr, Fe, Ga, Y, Zr and Nb): Journal of Petrology, v. 50, p. 1765-1794, http://dx.doi.org/10.1093/petrology/egp053.

Manikyamba, C., and Kerrich, R., 2011, Geochemistry of alkaline basalts and associated high-Mg basalts from the $2.7 \mathrm{Ga}$ Penakacherla Terrane, Dharwar craton, India: An Archean depleted mantle-OIB array: Precambrian Research, v. 188, p. 104-122, http://dx.doi.org/10.1016/j.precamres.2011.03.013.

Matzen, A.K., Baker, M.B., Beckett, J.R., and Stolper, E.M., 2011, Fe-Mg partitioning between olivine and high-magnesian melts and the nature of Hawaiian parental liquids: Journal of Petrology, v. 52, p. 1243-1263, http://dx.doi.org/ 10.1093/petrology/egq089.

McDonough, W.F., 2003, Compositional model for the Earth's core, in Carlson, R.W., ed., Volume 2: The Mantle and Core, Treatise on Geochemistry: ElsevierPergamon, Oxford, p. 547-568, http://dx.doi.org/10.1016/B0-08-0437516/02015-6.

Milner, S.C., and le Roex, A.P., 1996, Isotope characteristics of the Okenyenya igneous complex, northwestern Namibia; constraints on the composition of the early Tristan plume and the origin of the EM1 mantle component: Earth and Planetary Science Letters, v. 141, p. 277-291, http://dx.doi.org/ 10.1016/0012-821X(96)00074-X.

Montelli, R., Nolet, G., Dahlen, F.A., Masters, G., Engdahl, E.R., and Hung, S.-H., 2004, Finite-frequency tomography reveals a variety of plumes in the mantle: Science, v. 303, p. 338-343, http://dx.doi.org/10.1126/science.1092485.
Montelli, R., Nolet, G., Dahlen, F.A., and Masters, G., 2006, A catalogue of deep mantle plumes: New results from finite-frequency tomography: Geochemistry, Geophysics, Geosystems, v. 7, Q11007, http://dx.doi.org/10.1029/ 2006GC001248.

Mungall, J.E., and Naldrett, A.J., 2008, Ore deposits of the Platinum-group elements: Elements, v. 4, p. 253-258, http://dx.doi.org/10.2113/GSELEMENTS.4.4.253.

Naldrett, A.J., 2005, A history of our understanding of magmatic Ni-Cu sulphide deposits: The Canadian Mineralogist, v. 43, p. 2069-2098, http://dx.doi.org/ 10.2113/gscanmin.43.6.2069.

Nebel, O., Vroon, P.Z., Wiggers de Vries, D.F., Jenner, F.E., and Mavrogenes, J.A., 2010, Tungsten isotopes as tracers of core-mantle interactions: The influence of subducted sediments: Geochimica et Cosmochimica Acta, v. 74, p. 751-762, http://dx.doi.org/10.1016/j.gca.2009.10.017.

Nielsen, S.G., Rehkämaper, M., Norman, M.D., Halliday, A.N., and Harrison, D., 2006, Thallium isotopic evidence for ferromanganese sediments in the mantle source of Hawaiian basalts: Nature, v. 439, p. 314-317, http://dx.doi.org/ 10.1038 /nature 04450

Pearce, J.A., 1996, A user's guide to basalt discrimination diagrams, in Wyman, D.A. ed., Trace Element Geochemistry of Volcanic Rocks: Applications for Massive Sulphide Exploration: Geological Association of Canada, Short Course Notes 12, p. 79-113.

Pearce, J.A., and Cann, J.R., 1973, Tectonic setting of basic volcanic rocks determined using trace element analyses: Earth and Planetary Science Letters, v. 19, p. 290-300, http://dx.doi.org/10.1016/0012-821X(73)90129-5.

Qin, L., and Humayun, M., 2008, The Fe/Mn ratio in MORB and OIB determined by ICP-MS: Geochimica et Cosmochimica Acta, v. 72, p. 1660-1677, http://dx.doi.org/10.1016/j.gca.2008.01.012.

Roeder, P.L., and Emslie, R.F., 1970, Olivine-liquid equilibrium: Contributions to Mineralogy and Petrology, v. 29, p. 275-289, http://dx.doi.org/10.1007/ BF00371276.

Rouxel, O.J., Bekker, A., and Edwards, K.J., 2005, Iron isotope constraints on the Archean and Paleoproterozoic ocean redox state: Science, v. 307, p. 1088-1091, http://dx.doi.org/10.1126/science.1105692.

Said, N., and Kerrich, R., 2010, Magnesian dyke suites of the 2.7 Ga Kambalda Sequence, Western Australia: Evidence for coeval melting of plume asthenosphere and metasomatised lithospheric mantle: Precambrian Research, v. 180, p. 183-203, http://dx.doi.org/10.1016/j.precamres.2010.04.003.

Sarbas, B., and Nohl, U., 2008, The GEOROC database as part of a growing geoinformatics network, in Brady, S.R., Sinha, A.K., and Gundersen, L.C., eds., Geoinformatics 2008-Data to Knowledge: U.S. Geological Survey Scientific Investigations Report 2008-5172, p. 42-43.

Schaefer, B.F., Turner, S., Parkinson, I., Rogers, N., and Hawkesworth, C., 2002, Evidence for recycled Archean oceanic mantle lithosphere in the Azores plume: Nature, v. 420, p. 304-307, http://dx.doi.org/10.1038/nature01172.

Scherstén, A., Elliott, T., Hawkesworth, C., and Norman, M., 2004, Tungsten isotope evidence that mantle plumes contain no contribution from the Earth's core: Nature, v. 427, p. 234-237, http://dx.doi.org/10.1038/nature02221.

Sobolev, A.V., Hofmann, A.W., Sobolev, S.V., and Nikogosian, I.K., 2005, An olivine-free mantle source of Hawaiian shield basalts: Nature, v. 434, p. 590-597, http://dx.doi.org/10.1038/nature03411.

Sobolev, A.V., Hofmann, A.W., Kuzmin, D.V., Yaxley, G.M., Arndt, N.T., Chung, S.L., Danyushevsky, L.V., Elliott, T., Frey, F.A., Garcia, M.O., Gurenko, A.A., Kamenetsky, V.S., Kerr, A.C., Krivolutskaya, N.A., Matvienkov, V.V., Nikogosian, I.K., Rocholl, A., Sigurdsson, I.A., Sushchevskaya, N.M., and Teklay, M., 2007, The amount of recycled crust in sources of mantle-derived melts: Science, v. 316, p. 412-417, http://dx.doi.org/10.1126/Science. 1138113.

Sun, S.-S., and McDonough, W.F., 1989, Chemical and isotopic systematics of oceanic basalts: implications for mantle composition and processes, in Saunders, A.D., and Norry, M.J., eds., Magmatism in the Ocean Basins: Geological Society, London, Special Publications, v. 42, p. 313-345, http://dx.doi.org/ 10.1144/GSL.SP.1989.042.01.19

Tatsumi, Y., 2000, Continental crust formation by crustal delamination in subduction zones and complementary accumulation of the enriched mantle I component in the mantle: Geochemistry, Geophysics, Geosystems, v. 1, 1053, http://dx/doi.org/10.1029/2000GC000094.

Toplis, M.J., 2005, The thermodynamics of iron and magnesium partitioning between olivine and liquid: criteria for assessing and predicting equilibrium in natural and experimental systems: Contributions to Mineralogy and Petrology, v. 149, p. 22-39, http://dx.doi.org/10.1007/s00410-004-0629-4.

Wang, Z.R., and Gaetani, G.A., 2008, Partitioning of Ni between olivine and siliceous eclogite partial melt: experimental constraints on the mantle source of Hawaiian basalts: Contributions to Mineralogy and Petrology, v. 156, p. 661-678, http://dx.doi.org/10.1007/s00410-008-0308-y.

Weaver, B.L., 1991, The origin of ocean island basalt end-member compositions: trace element and isotopic constraints: Earth and Planetary Science Letters, v. 
104, p. 381-397, http://dx.doi.org/10.1016/0012-821X(91)90217-6.

Wilkinson, L., Hill, M., Welna, J.P., and Birkenbeuel, G.K., 1992, SYSTAT for Windows: Statistics, Version 5, SYSTAT Inc., Evanston, IL.

Willbold, M., Elliott, T., and Archer, C., 2009, $\varepsilon^{182} \mathrm{~W}$ in ocean island basalts and the role of core-mantle interaction (Abstract): Goldschmidt Conference, Geochimica et Cosmochimica Acta, Supplementary, 73, Davos, Switzerland, A1444.

Zhang, M., O’Reilly, S.Y., Wang, K.-L., Hronsky, J., and Griffin, W.L., 2008, Flood basalts and metallogeny: The lithospheric mantle connection: Earth-Science Reviews, v. 86, p. 145-174, http://dx.doi.org/10.1016/j.earscirev.2007.08.007.

Zindler, A., and Hart, S., 1986, Chemical geodynamics: Annual Review of Earth and Planetary Sciences, v. 14, p. 493-571, http://dx.doi.org/10.1146/ annurev.ea.14.050186.002425.

\section{Received March 2015}

Accepted March 2015

First published on the web June 2015

For access to Greenough and MacKenzie (2015) electronic supplementary materials (ESM Tables 1 through 4), please visit GAC's open source GC Data Repository, Igneous Rock Associations link at: http://www.gac.ca/wp/?page_id=306. 


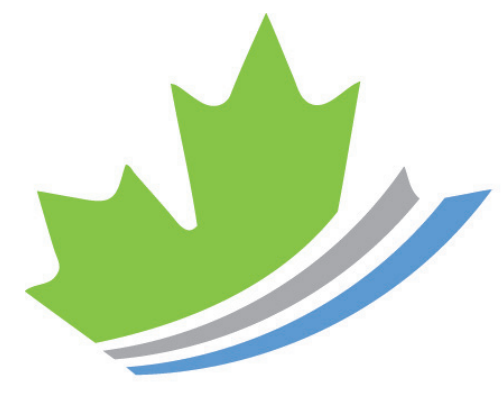

\section{GEOLOGICAL ASSOCIATION OF CANADA}

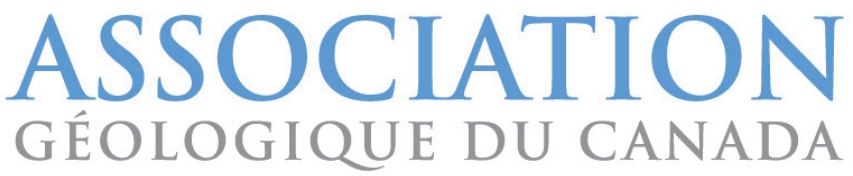

WE SELL BOOKS

Reeltime Geological Syntheses: Remembering Harold "Hank" Williams Facies Models 4 Geology of Mineral Resources Mineral Deposits of Canada Atlas of Alteration Ore Mineral Atlas

Palaeontographica Canadiana series

\section{We Host Conferences}

Whitehorse, June 1-3, 2016 whitehorse2016.ca

Kingston, ON, 2017

Vancouver, BC, 2018

\section{We Publish A Journal}

Geoscience Canada

\section{We ACKNOWLEDGe Distinction}

Logan Medal

W.W. Hutchison Medal

E.R.Ward Neale Medal

J. Willis Ambrose Medal

Mary-Claire Ward Geoscience Award Yves Fortier Earth Science Journalism Award ...and many more!

\section{SUPPORT US TODAY}

7098647660

gac@mun.ca

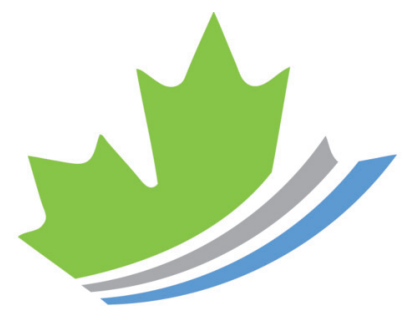

www.gac.ca 